
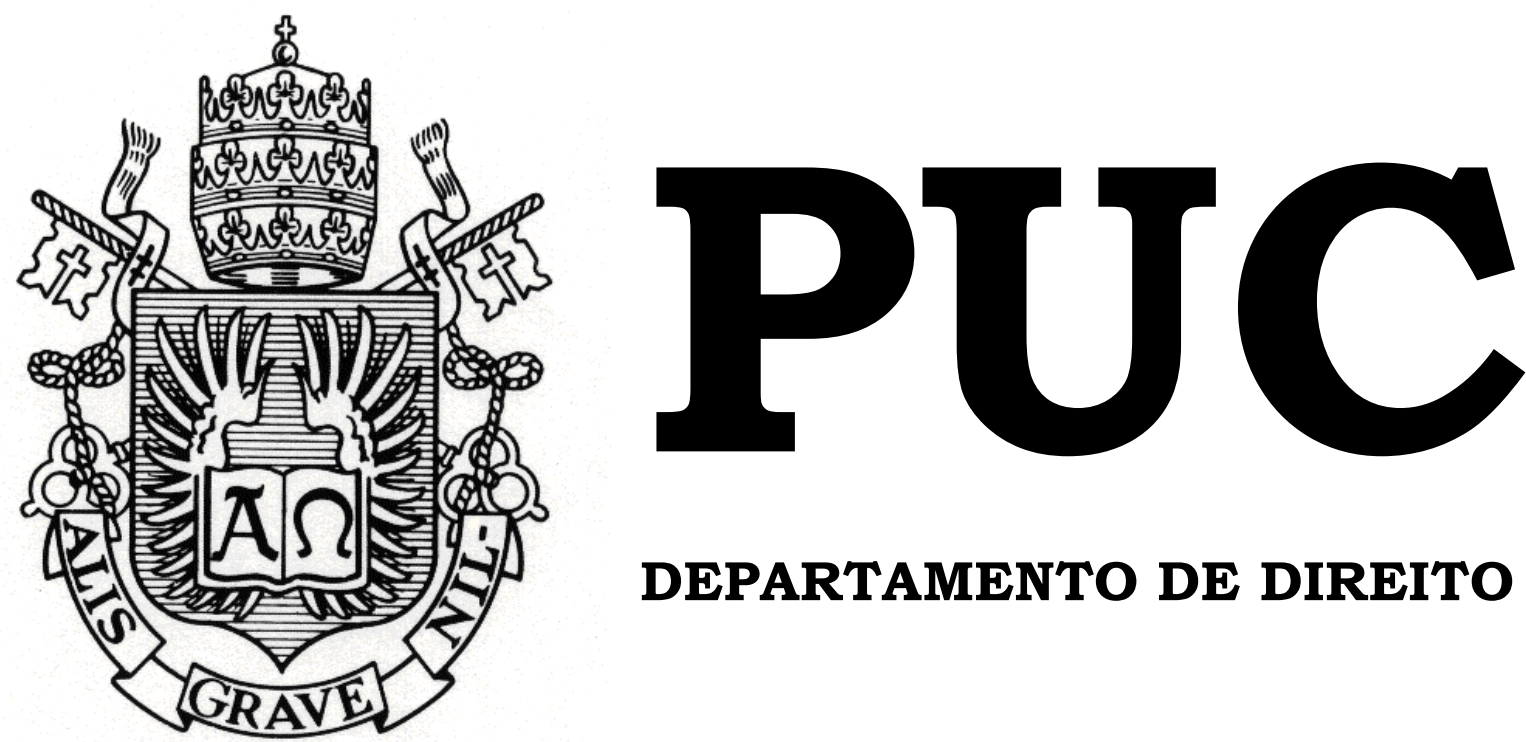

DEPARTAMENTO DE DIREITO

\title{
O PAPEL DO MINISTÉRIO PÚBLICO NA USUCAPIÃO E NAS AÇÕES POSSESSÓRIAS COM O ADVENTO DO NCPC
}

por

LUCAS DO AMARAL LEITE

ORIENTADOR: ADOLFO BORGES FILHO

2018.1

PONTIFÍCIA UNIVERSIDADE CATÓLICA DO RIO DE JANEIRO

RUA MARQUÊS DE SÃO VICENTE, 225 - CEP 22453-900

RIO DE JANEIRO - BRASIL 


\title{
O PAPEL DO MINISTÉRIO PÚBLICO NA USUCAPIÃO E NAS AÇÕES POSSESSÓRIAS COM O ADVENTO DO NCPC
}

\author{
por
}

\section{LUCAS DO AMARAL LEITE}

Monografia apresentada ao Departamento de Direito da Pontificia Universidade Católica do Rio de Janeiro (PUC-Rio) como requisito parcial para a obtenção do Título de Bacharel em Direito.

Orientador: Adolfo Borges Filho 


\section{RESUMO}

A presente monografia tem como objetivo delinear a atuação do Ministério Público, através das Promotorias de Justiças Cíveis, nas ações possessórias e nas ações de usucapião com a nova sistemática trazida lei 13.105/15 (Novo Código de Processo Civil).

Para tanto, inicialmente nos debruçaremos nos institutos da usucapião, das ações possessórias, assim como do papel do Parquet no âmbito cível, esmiuçando suas características e variáveis no âmbito material e processual.

A partir desse arcabouço, analisaremos como se apresentava a intervenção ministerial, à luz do Código de Processo Civil de 1973, nos institutos supracitados, cotejando a previsão legal e a jurisprudência acerca do tema.

Posteriormente, o nosso enfoque recairá sobre as mudanças advindas da vigência da nova legislação processual civil brasileira, verificando como vem tratada a matéria no âmbito da legislação, a recente jurisprudência sobre o tema, o posicionamento dos Promotores de Justiça a respeito das modificações e a lentidão da mudança de paradigma na prática forense.

Por fim, este trabalho apresentará as implicações práticas, o quão benéficas, ou não, são para o Ministério Público e para a sociedade em si, como um todo, essas alterações legislativas colocadas pelo Novo Código de Processo Civil.

\section{Palavras-Chave:}

Posse - Propriedade - Ministério Público - Ações Possessórias - Usucapião Código de Processo Civil de 1973 - Novo Código de Processo Civil Promotores de Justiça - Jurisprudência - Alterações legislativas - Lentidão da mudança prática de paradigma - Implicações Práticas. 
SUMÁRIO

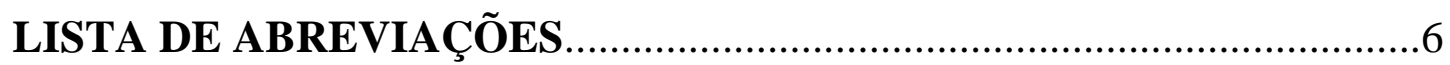

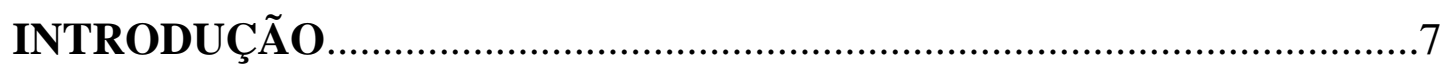

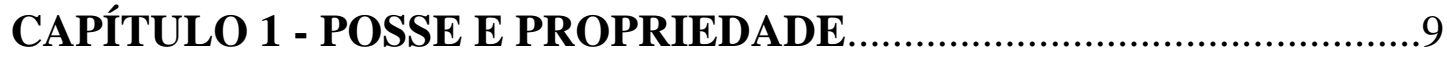

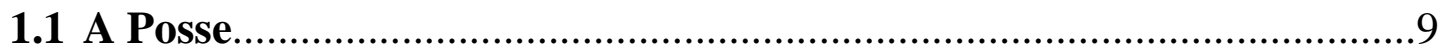

1.1.1 Conceito de posse e Teorias Clássicas................................................

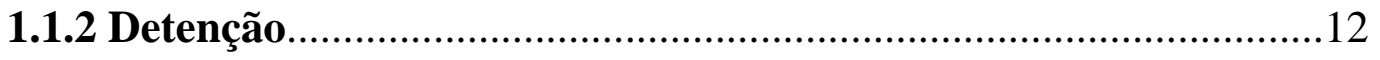

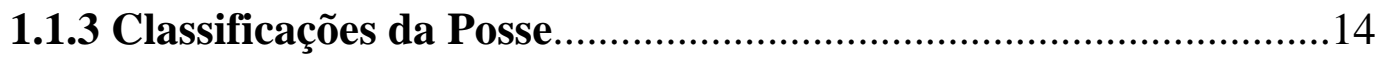

1.1.4 Formas de aquisição da Posse.......................................................18

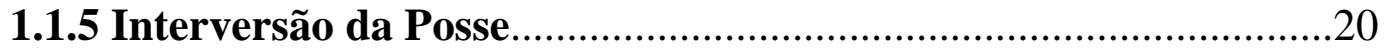

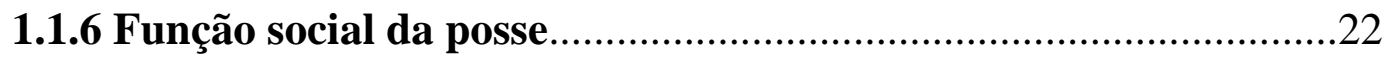

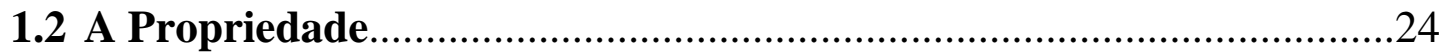

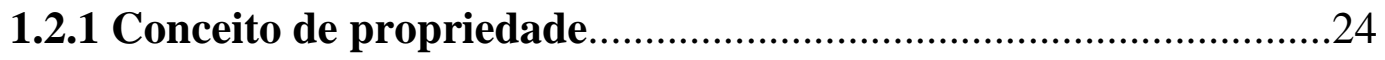

1.2.2 Estrutura do direito de propriedade............................................26

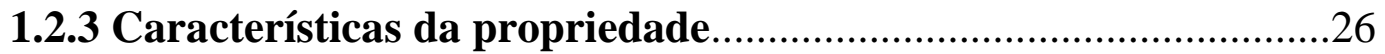

1.2.4 Formas de aquisição da propriedade...........................................28

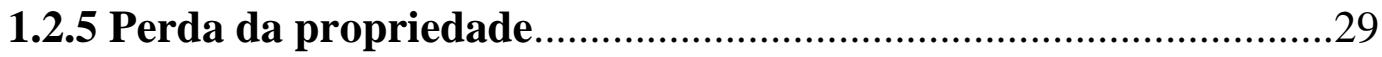

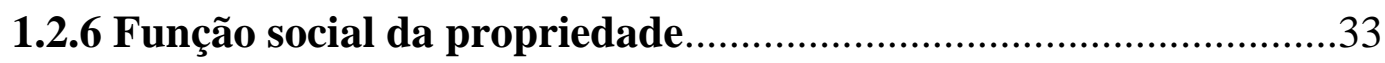

CAPÍTULO 2 - USUCAPIÃO, AÇÕES POSSESSÓRIAS E MINISTÉRIO PÚBLICO NA TUTELA POSSESSÓRIA............................36

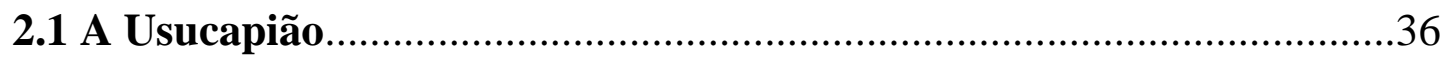

2.1.1 Conceito e fundamentação da usucapião...................................36

2.1.2 Espécies de usucapião de bens imóveis.......................................38

2.1.2.1 Usucapião extraordinária.................................................38

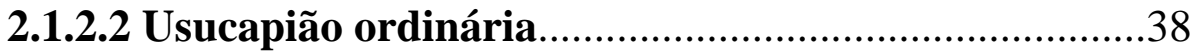

2.1.2.3 Usucapião especial rural.............................................. 41

2.1.2.4 Usucapião especial urbana............................................42

2.1.2.5 Usucapião por abandono do lar.....................................44 


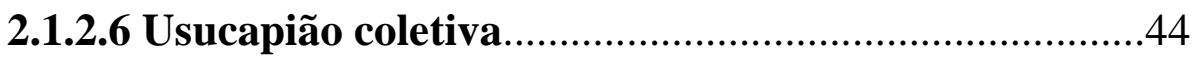

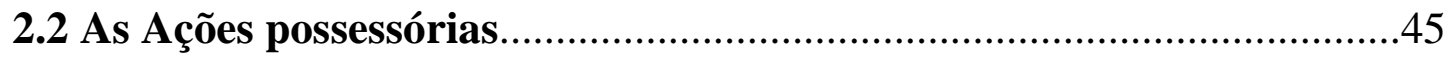

2.2.1 Disposições gerais das ações possessórias...................................45

2.2.2 Ação de manutenção de posse....................................................46

2.2.3 Ação de reintegração de posse..................................................47

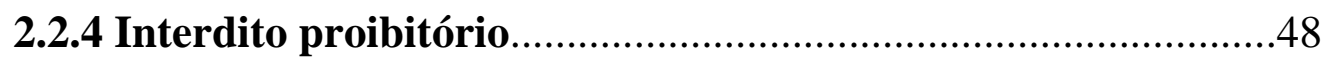

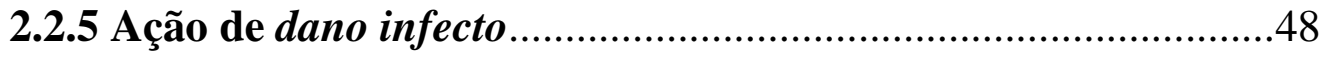

2.2.6 Ação de nunciação de obra nova................................................49

2.2.7 Ação de imissão na posse.........................................................50

2.3 A Função do Ministério Público no âmbito cível.....................................50

2.3.1 Ministério Público previsão geral.............................................50

2.3.2 Promotorias de Justiça Cíveis...................................................51

2.3.3 Promotorias de Justiça Cíveis stricto sensu ...............................52

CAPÍTULO 3 - ATUAÇÃO DO MINISTÉRIO PÚBLICO NO CÓDIGO

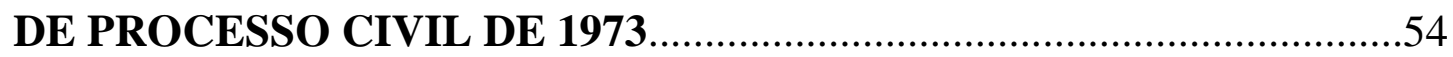

3.1 Regramento do $\mathrm{CPC} / 73$ e a expressa previsão de intervenção

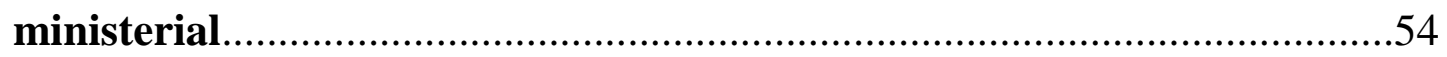

3.2 Modalidades de intervenção do MP nas ações de usucapião................55

3.3 Atuação do MP nas ações possessórias.................................................57

3.4 Jurisprudência à luz do CPC/1973 ..................................................58

CAPÍtUlO 4 - NOVO REGRAMENTO TRAZIDO PELO NOVO CÓDIGO DE PROCESSO CIVIL............................................................67

4.1 Regramento do CPC/15 e a nova interferência do Parquet....................67

4.2 Interpretação civil-constitucional do Art.178, CPC, nas ações

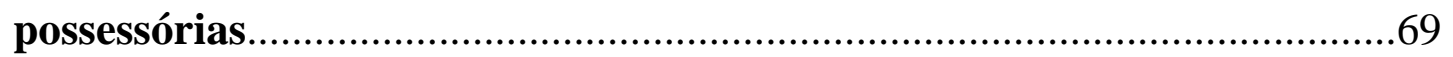

4.3 Omissão Legal do NCPC quanto a atuação do MP nas ações de

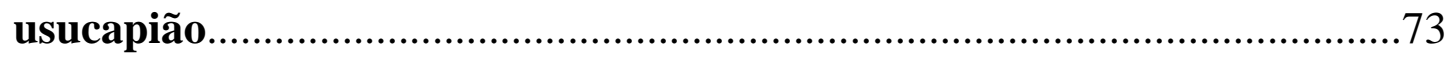

4.4 Posições dos Promotores de Justiça Cíveis............................................76

4.5 Lentidão da mudança prática de paradigma..........................................80 


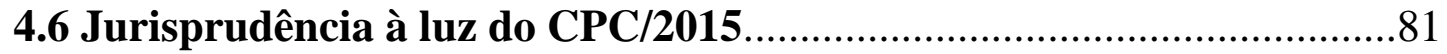

CONCLUSÃO

5.1 Implicações práticas e efeitos da modificação legislativa....................87

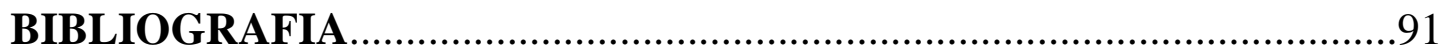




\section{LISTA DE ABREVIAÇÕES}

Art. - Artigo

CC/2002 - Código Civil de 2002

CJF - Conselho da Justiça Federal

CPC/1973 - Código de Processo Civil de 1973

CPC/2015 - Código de Processo Civil de 2015

CRFB - Constituição da República Federativa do Brasil

MP - Ministério Público

NCPC - Novo Código de Processo Civil

STF - Supremo Tribunal Federal 


\section{INTRODUÇÃO}

A presente monografia tem como objetivo estudar e se posicionar acerca da atribuição do Ministério Público nas ações possessórias e nas ações de usucapião com o advento do Novo Código de Processo Civil.

O intuito é analisar como se dava a intervenção ministerial à luz do antigo Código de Processo Civil para se examinar a atual, trazendo, para isso, a mudança legislativa, a posição dos promotores de justiça, bem como a jurisprudência dos tribunais sobre o tema.

Para que ocorra o real entendimento da discussão, inicialmente se tratará dos institutos da posse e da propriedade, porque sem eles, impossível adentrar no que se pretende.

Fixados esses parâmetros iniciais, analisar-se-ão o que vem a ser uma ação possessória e suas principais modalidades, assim como a ação de usucapião, com as suas espécies e, ainda, a função do Ministério Público, sobretudo no âmbito cível, uma vez que cabe a este atuar nessas ações, como adiante se verá.

A partir dessa base, mergulhar-se-á no contexto estabelecido pelo CPC/1973, tratando da fundamentação do funcionamento do Parquet nas ações possessórias, na usucapião, retendo-se as espécies e modalidades de intervenção, além da consolidada jurisprudência sob a égide do antigo diploma processual.

Em seguida, o cuidado será em relação a nova sistemática inaugurada pelo CPC/2015, trazendo a mudança da legislação, as discussões sobre o tema, as novas hipóteses de atuação do Ministério Público, a jurisprudência recente sobre o assunto, a lentidão da alteração de postura do MP, assim como o posicionamento dos promotores de justiça que lidam, na prática, com a questão. 
Por fim, tudo isso colocado e examinado, apresentar-se-ão as implicações práticas dessa mudança, se positivas ou não, à coletividade como um todo e também ao próprio Ministério Público, no que diz respeito a qualidade do serviço prestado. 



\section{Capítulo 1 - Posse e Propriedade}

\subsection{Posse}

\subsubsection{Conceito de posse e Teorias Clássicas}

$A b$ initio, para que possa se tratar do papel do Ministério Público na usucapião e nas ações possessórias, fundamental retroceder um pouco para ver e entender em que se configura a posse e a propriedade, porque a partir da compreensão desses institutos, mais clara ficará a análise.

Assim, passa-se a esmiuçar a posse e suas implicações, para, em seguida, se debruçar sobre o instituto da propriedade.

Isto posto, posse é um estado de fato sobre a coisa, é o senhorio sobre a coisa, é tê-la como se dono fosse, sendo efetivamente dono ou não.

Todavia, nem todo o estado de fato relativo à coisa é posse, uma vez que pode não se passar de mera detenção, que é um instituto que muito se aproxima da posse, mas que tem efeitos jurídicos completamente distintos ${ }^{1}$.

Nesse sentido, ao falar de posse, impossível não se referir ao conceito de possuidor, que é justamente aquele que tem posse.

Seu conceito é encontrado no art. 1.196, CC/2002.

$\mathrm{O}$ referido artigo apresenta o possuidor como aquele que exerce um dos poderes da propriedade, sendo que estes poderes estão no art. 1.228, CC/02 e são os poderes de usar, gozar, dispor e reivindicar a propriedade.

O possuidor, portanto, exerce pelo menos um desses 4 (quatro) poderes inerentes a propriedade, porque se não exercer, possuidor não será.

A principal característica da propriedade é ser um direito real elástico, isto é, o proprietário pode exercer um dos poderes relativos a propriedade na

\footnotetext{
${ }^{1}$ PEREIRA, Caio Mário da Silva. Instituições de Direito Civil. Volume IV. Direitos Reais. $23^{\text {a }}$ ed. Rio de Janeiro, Forense, 2015. p.13.
} 
sua integralidade ou não, podendo, assim, abrir mão de algum desses em favor de outrem ${ }^{2}$.

O proprietário pode ceder o direito de usar a propriedade, como nos casos da locação, do comodato ou do usufruto, assim como de gozar à coisa, que diz respeito ao acesso os frutos do bem, como também nas hipóteses de usufruto e de sublocação.

Dessa forma, o possuidor pode fazer uso desses poderes, porém não pode dispor da propriedade da coisa (alienar), já que somente o proprietário pode exercer este poder. Só o proprietário pode reivindicar a propriedade do bem, em que pese o direito do possuidor de reivindicar a posse do bem.

Portanto, os poderes de dispor e reivindicar estão sempre com o proprietário.

Dito isso, se o possuidor é aquele que exerce um dos poderes da propriedade e proprietário, por sua vez, sempre estará exercendo ao menos dois desses poderes (dispor e reivindicar), se conclui que o proprietário será também sempre um possuidor, podendo ser, a depender da situação configurada, possuidor direto, indireto ou pleno.

É por isso que existem as figuras oriundas do direito romano, ius possessionis, que nada mais é do que a posse do não proprietário, daquele que não tem a propriedade e o ius posidendi, que se traduz na posse proprietária, ou seja, a posse de quem é proprietário ${ }^{3}$.

Avançando, examinar-se-á as teorias possessórias clássicas - apesar de saber que existem inúmeras teorias da posse - que dividem a doutrina e

\footnotetext{
${ }^{2}$ LEITE, Gisele. Propriedade em geral em poucas palavras. In: Âmbito Jurídico, Rio Grande, XI, n.50, fev. $2008.2 \quad$ Disponível em $\quad<$ http://www.ambitojuridico.com.br/site/?n_link=revista_artigos_leitura\&artigo_id=4556\&revista_caderno=7>. Acesso em 10 nov. 2017.

${ }^{3}$ CARVAlHO, Fabio Rodrigues de. Diferença entre o Ius Possessionis e o Ius Possidendi. Disponível em <https://lfg.jusbrasil.com.br/noticias/47734/qual-a-diferenca-entre-jus-possessionis-e-por-juspossidendi>. Acesso em 12 nov. 2017.
} 
possuem evidente repercussão legislativa, que são as teorias subjetiva de Savigny e objetiva de Jhering ${ }^{4}$.

A teoria subjetiva da posse desenvolvida por Savigny explana que para haver posse, dois elementos essenciais devem estar presentes, quais sejam, o animus domini e o corpus ${ }^{5}$.

O corpus se revela no contato efetivo com a coisa, enquanto que o animus domini nada mais é do que a intenção de ser proprietário dessa coisa.

Diga-se de passagem, que essa teoria jamais foi admitida no direito brasileiro, porquanto ela exclui do conceito de posse uma série de situações fático-jurídicas concretas relevantes.

Dizendo de outro modo, para essa teoria, o locatário, o comodatário, o usufrutuário e o depositário, por exemplo, não são possuidores, pois nenhuma dessas pessoas possui a intenção de ser proprietária da coisa.

Outrossim, a teoria que se admite no Brasil é a teoria objetiva da posse, criada por Jhering. Tal teoria apresenta que é imprescindível a presença de dois elementos também para se ter posse, mas esses elementos, ao contrário da teoria subjetiva, são outros. Ela diz que além do corpus, que seria a sujeição da coisa a vontade do possuidor, o affectio tenendi tem que estar presente para haver posse. O affectio tenendi é o agir como se fosse proprietário e não a intenção de ser dono ${ }^{6}$.

Então, para Jhering, para se ter posse teria que se ter a coisa sujeita à vontade de alguém, aliada ao agir como se fosse proprietário.

Como já colocado, no Brasil se adotou a teoria de Jhering, uma vez que da análise do art. 1.196, CC/2002, depreende-se que a legislação prestigiou o affectio tenendi, visto que o aludido dispositivo elucida que possuidor é quem

\footnotetext{
4 (1) PEREIRA, Caio Mário da Silva. Op. cit., p.14.

${ }^{5}$ (2) Ibid. p. 16.

${ }^{6}$ (3) Ibid. p. 17.
} 
exerce um dos poderes da propriedade, logo, é possuidor quem age como se fosse dono, sendo desnecessária a intenção de ser dono efetivo.

Para Jhering, posse é a exteriorização da propriedade, o que denota que, nessa acepção, o conceito de posse está intimamente ligado a propriedade. Desta maneira, ele vincula o conceito de posse ao conceito de propriedade ${ }^{7}$.

\subsubsection{Detenção}

A posse produz efeitos jurídicos, porque se revela como um direito, no entanto, a detenção, por mais que se aproxime do instituto da posse, é um instituto completamente diverso, já que se traduz em uma situação fática que não tem o condão de gerar repercussões jurídicas ${ }^{8}$.

O detentor, dessa forma, não pode, por exemplo, (i) fazer uso de ação possessória, (ii) ser indenizado por benfeitorias, sejam elas quais forem, (iii) usucapir o bem.

Para a teoria subjetiva da posse de Savigny, anteriormente vista, a detenção é a presença do corpus sem o outro elemento da posse, isto é, o animus domini. Nessa linha de raciocínio, pessoas como o locatário, o usufrutuário, o comodatário seriam mero detentores, visto que têm o contato com a coisa (corpus), mas, por outro lado, não possuem a intenção de ser proprietário dela.

Por sua vez, na visão objetiva da posse de Jhering, os casos de detenção são aqueles que a lei assim define, portanto, haverá detenção quando e nos termos que a legislação estabelecer.

O código civil de 2002, como adotou a teoria objetiva, definiu as hipóteses de detenção no ordenamento jurídico brasileiro, estando elas regradas nos arts. 1.198 e $1.208,1^{\mathrm{a}}$ parte, ambos do CC/2002.

\footnotetext{
${ }^{7}$ GONÇALVES, Carlos Roberto. Direito civil brasileiro: direito das coisas. 6. ed. São Paulo: Saraiva, 2011.

${ }^{8}$ PEREIRA, Caio Mário da Silva. Op. cit., p.13.
} 
O detentor que diz respeito o art. 1.198, CC/2002 é aquele que conserva a coisa em nome de outrem, dada uma relação de subordinação. Ele é o serviçal, ou, também conhecido como fâmulo da posse.

Se constituem nessa espécie de detentor o caseiro, o porteiro, a empregada doméstica, o motorista, por exemplo, já que todos esses tem o dever de zelo para com a coisa, a conservando, entretanto, em momento algum fazem em nome próprio, mas sim, em nome de outrem, justamente pela relação de subordinação travada para com o proprietário.

A outra espécie de detenção é a revelada pelo art. 1.208, $1^{\mathrm{a}}$ parte, CC/2002, que preconiza que não induzem em posse os atos de mera permissão ou tolerância. Então, aquele que ocupa o bem apenas pela permissão ou tolerância do proprietário será mero detentor, não possuindo a sua ocupação repercussões jurídicas.

A inexistência de uma relação contratual, como um contrato de comodato, por exemplo, faz com que se esteja diante de uma detenção, ao invés de uma situação de posse. Isso é que acontece, verbi gratia, com o particular que ocupa um bem público sem relação contratual com o Poder Público competente.

Para não dizer que a detenção não gera efeito nenhum, o único efeito da posse que é a ela estendido é a possibilidade do detentor fazer uso da força para proteger a coisa de possíveis violações perpetradas por terceiros, isto é, o exercício da autotutela da posse, positivado no art. $1.210, \S 1^{\circ}, \mathrm{CC} / 2002^{9}$.

A doutrina não é uníssona no tema, até porque a interpretação literal reflete que esse é um direito do possuidor, mas se assim não fosse, o detentor, sobretudo o do art. 1.198, CC/2002, não poderia promover o seu dever de conservação que é a sua pessoa inerente, restando este inútil, em certos casos.

${ }^{9}$ BLOG, Direito Direto. Disponível em <https://direitodiretoblog.wordpress.com/2016/11/26/o-merodetentor-da-coisa-pode-se-valer-da-autotutela-desforco-imediato>. Acesso em 19 nov. 2017. 
Contudo, a utilização da força nesta hipótese desse ser proporcional, uma vez que se desarrazoada for, gerará responsabilidade civil.

Outro ponto que merece defesa em favor do detentor, por uma construção lógica, menos debatido ainda, é a possibilidade de ser indenizado pelas benfeitorias necessárias que realizar ${ }^{10}$.

Isso porque, em situações emergenciais que demandem o emprego que um ato comissivo necessário à preservação do bem, não poder-se-ia admitir que o detentor deixasse a coisa deteriorar, simplesmente por um obstáculo legal.

Assim, considerando a boa-fé aplicada pelo detentor, bem como a vedação ao enriquecimento sem causa do proprietário beneficiado de um malefício maior, conforme art. 884, CC/2002, necessária se faz a indenização pelas benfeitorias necessárias realizadas de boa-fé.

Aqui, nota-se, não se analisa a relação do detentor para com a coisa, não se trata de relação de direito real, muito pelo contrário, a análise tem que ser feita na relação entre detentor e proprietário, ou seja, um exame do liame pessoal entre essas duas figuras, que se traduz em uma situação jurídica de caráter existencial.

\subsubsection{Classificações da posse}

Quanto a classificação, a posse pode ser categorizada de várias maneiras, cujas explicações virão a seguir.

A posse poder ser inicialmente classificada em posse direta e posse indireta, nos moldes do art. 1.197, CC/2002.

Veja-se a redação, in verbis:

Art. 1.197. A posse direta, de pessoa que tem a coisa em seu poder, temporariamente, em virtude de direito pessoal, ou real, não anula a indireta, de

10 DIAS, Nadir Silveira. Benfeitorias em imóveis: Considerações gerais. In: Âmbito Jurídico, Rio Grande, II, n. 5, maio 2001. Disponível em: <http://www.ambitojuridico.com.br/site/?n_link=revista_artigos_leitura\&artigo_id=2027\&revista_caderno=7>. Acesso em 20 nov. 2017. 
quem aquela foi havida, podendo o possuidor direto defender a sua posse contra o indireto ${ }^{11}$.

Esse dispositivo admite que haja um desdobramento da posse e este pode ser oriundo de um direito real ou de um direito pessoal.

O desdobramento decorrente de um direito real pode ser visto, por exemplo, no usufruto, em que o nu-proprietário é o possuidor indireto e o usufrutuário é o possuidor direto, ou no penhor, em que o credor é o possuidor direto e o devedor o indireto.

De outro modo, o desmembramento pautado em um direito pessoal pode ser verificado, à título de exemplo, na locação, em que o locador é o possuidor direto e o locatário indireto, no comodato, onde o comodante é o possuidor indireto e o comodatário é o possuidor direto, ou, no depósito, sendo o depositante o possuidor indireto e depositário o possuidor direto.

Tanto o possuidor direto, quanto o indireto podem fazer uso das ações possessórias contra aquele que injustamente a possua ou detenha, podendo, inclusive, manejá-las em face um do outro, de modo que não necessariamente no embate entre duas posses, a indireta, isto é, a do proprietário seja a melhor $^{12}$.

Outra classificação divide a posse em justa e injusta, de acordo com os termos do art. 1.200, CC/2002. Da análise a contrario sensu do artigo, depreende-se que a posse injusta é aquela que está maculada com algum dos vícios objetivos da posse, ou, dizendo de outra forma, a posse injusta é a posse eivada de violência, clandestinidade ou precariedade ${ }^{13}$.

\footnotetext{
${ }^{11}$ BRASIL. Código Civil. Organização Yussef Said Cahali. 15a ed. rev. ampl. e atual. São Paulo. RT, 2013.

${ }^{12}$ BUENO, Julio César et al.. Ações possessórias e reivindicatórias - distinção e aspectos controversos. Disponível em <http://www.migalhas.com.br/dePeso/16,MI24726,61044Acoes+possessorias+e+reivindicatorias+distincao+e+aspectos>. Acesso em 08 dez. 2017.

${ }^{13}$ ZULIANI, Matheus Stamillo Santarelli. Posse justa e posse injusta: aplicações práticas e teóricas. Disponível em <http://www.migalhas.com.br/dePeso/16,MI64980,101048Posse+justa+e+posse+injusta+aplicacoes+praticas+e+teoricas $>$. Acesso em 09 dez. 2017.
} 
A consequência da posse estar maculada com algum desses vícios, segundo o art. $1.200 \mathrm{c} / \mathrm{c}$ art. $1.208,2^{\mathrm{a}}$ parte, $\mathrm{CC} / 2002$, é que ela não produzirá efeitos jurídicos, até que se cesse-os.

Muito embora o art. 1.208, $2^{\mathrm{a}}$ parte fale tão somente da violência e da clandestinidade, na medida em a posse só produzirá efeitos quando cessados esses vícios, a precariedade também faz com que não se produza efeitos, pela interpretação a contrario sensu do art. 1.200, CC/2002, acerca de posse injusta. E este vício só não está contemplado pelo art. 1208, $2^{\mathrm{a}}$ parte, CC/2002, também, pelo simples fato da precariedade ser o único desses 3 (três) vícios que não pode ser cessado com o tempo, logo, foi suprimido deste dispositivo.

Isto posto, importante discriminar as posses violenta, clandestina e precária.

A posse violenta é aquela adquirida através do uso da força, ao passo que a posse clandestina é conquistada na obscuridade, ou seja, sem a ciência do verdadeiro interessado. Por fim, a posse precária é a conseguida com abuso de confiança.

Exemplificando, a posse violenta se dá quando alguém invade uma residência alheia e nela se instala, sem a anuência e contra a vontade do proprietário, enquanto que a clandestina se opera em um contrato de sublocação sem o conhecimento do proprietário e, por último, a posse precária se constitui no momento em que o comodatário deveria restituir o bem ao comodante e não o faz, resistindo a devolução.

Uma terceira classificação possessória a subdivide em posse de boa-fé e em posse de má-fé.

A boa-fé aqui tratada é a boa-fé subjetiva trazida pelo art. 1.201, CC/2002, que nada mais é do que a boa-fé quanto ao conhecimento. Em termos de posse, essa boa-fé é melhor entendida quando existe um obstáculo a aquisição da posse, pois, havendo obstáculo, se estará de boa-fé quando não 
tiver ciência desse obstáculo ao adquirir a posse, porque uma vez tendo conhecimento do fator impeditivo e ignorá-lo, de má-fé estará. Não havendo obstáculo, por óbvio, o possuidor estará agindo de boa-fé14 .

Em que pese a posse de má-fé se aproximar muito de uma posse injusta, seus efeitos jurídicos são muito diferentes, na medida que enquanto a posse injusta carece de produção de efeitos, a posse de má-fé, por mais que não produza os mesmos efeitos da posse de boa-fé, produzirá certos efeitos jurídicos sim.

De todo modo, a posse de boa-fé é muito mais protegida pelo ordenamento jurídico pátrio brasileiro do que a posse de má-fé.

Com efeito, o possuidor de boa-fé, segundo o disposto no art. 1.214, CC/2002, tem direito aos frutos percebidos, ao passo que o possuidor de má-fé responde por todos os frutos colhidos e percebidos, bem como pelos que, por sua culpa, deixou de perceber, conforme art. 1.216, CC/2002.

Além disso, o art. 1.217, CC/2002 dispõe que o possuidor de boa-fé não responde pela perda ou deterioração da coisa a que não der causa, enquanto que o possuidor de má-fé responde ainda que a perda ou deterioração seja acidental. Nota-se, aqui, que o legislador impôs pena excessivamente gravosa ao possuidor de má-fé, não incentivando tal conduta.

Uma outra diferença de tratamento diz respeito a indenização das benfeitorias realizadas, já que o possuidor de boa-fé terá direito a ser indenizado no caso de benfeitorias necessárias e úteis, bem como das voluptuárias, caso consiga levantá-las, sem deteriorar a coisa (art. 1.219, CC/2002), tendo, inclusive, direito de retenção garantido quanto as necessárias e úteis. Por sua vez, o possuidor de má-fé não terá direito ao levantamento das benfeitorias voluptuárias, não lhe assistindo também direito de retenção em

\footnotetext{
${ }^{14}$ PEREIRA, Caio Mário da Silva. Op. cit., p. 23-24.
} 
nenhuma hipótese, restando a ele, tão somente, a indenização pelas benfeitorias necessárias (art. 1.220, CC/2002).

Por último, nesse tocante, uma distinção importante para os fins da presente monografia se apresenta no prazo para usucapião de um imóvel, já que com justo título e de boa-fé, se aplica o regime da usucapião ordinária (prazo de 10 anos para usucapir), que tem prazo reduzido frente a usucapião extraordinária (prazo de 15 anos para usucapir), modalidade pela qual pode se valer o possuidor de má-fé ${ }^{15}$.

\subsubsection{Formas de aquisição da posse}

Outro ponto atinente a posse gira em torno da sua forma de aquisição, que pode ocorrer de forma originária ou derivada.

A forma originária de aquisição da posse se dá pela prática de um ato material, que é a ocupação. No direito brasileiro, por sinal, a ocupação é uma forma de aquisição originária tanto da posse, quanto da propriedade.

Caio Mário, doutrinador de referência, utiliza, no entanto, a terminologia "apreensão" como forma de aquisição originária da posse ${ }^{16}$, assim como outros doutrinadores como Flavio Tartuce ${ }^{17}$, mas, data vênia, parece que o referido instituto se molda melhor a aquisição originária da posse de bem móvel.

$\mathrm{O}$ art. 1.204, CC/2002 ao estipular que a posse é adquirida desde o momento em que se torna possível exercer um dos poderes inerentes à propriedade, em nome próprio, quis, ao que parece, revelar que a ocupação é a

\footnotetext{
${ }^{15}$ MELLO, Bernardo de. Quais as consequências práticas da distinção entre posse de boa-fé e posse de má-fé?. Disponível em <https://direitodiario.com.br/consequencias-praticas-distincao-posse-boa-fe-ede-ma-fe/>. Acesso em 15 dez. 2017.

${ }^{16}$ PEREIRA, Caio Mário da Silva. Op. cit., p. 37.

${ }^{17}$ TARTUCCE, Flávio. Direito Civil. Direito das Coisas, $9^{\mathrm{a}}$ ed. rev., atual e ampliada. Rio de Janeiro: Forense, 2017. p. 65.
} 
forma pela qual se adquire a posse, justamente pelo fato da ocupação permitir o início da irradiação desses poderes por alguém.

A usucapião, como se verá infra é modo de aquisição originário também, no entanto, não da posse como a ocupação, mas sim da propriedade.

A outra forma de aquisição da posse é a derivada, que se instrumentaliza por meio de um ato negocial, notadamente a celebração de negócios jurídicos (podem ser informais como uma simples tradição). Portanto, a posse é um estado de fato sobre a coisa que pode ser negociado, em outras palavras, pode ser objeto de negócio jurídico.

O direito disciplina duas cláusulas em atos bilaterais que negociam a posse e são elas a traditio brevi manus e o constituto possessório ${ }^{18}$.

$\mathrm{O}$ traditio brevi manus consiste na cláusula que faz com que o possuidor direto se torne possuidor pleno, como um locatário que adquire para si o imóvel locado de propriedade do locador.

Por haver uma tradição da titularidade da coisa, trata-se de aquisição derivada da posse realizada através de um negócio jurídico.

O constituto possessório, por outro lado, é uma cláusula que possibilita a transmissão ficta da posse.

Outrossim, um promitente vendedor que celebra uma promessa de compra e venda com o promitente comprador, além de já permitir a posse direta deste até o adimplemento final, pode lhe transferir a posse plena através do constituto possessório, de modo que o promitente vendedor seja um proprietário sem posse. Uma vez concretizada essa cláusula, o promitente vendedor perde o direito de mover ação possessória em face do promitente comprador, visto que ele não é mais possuidor, nem direto, nem indireto. Com isso, o deslinde da controvérsia se dará de forma adequada com a propositura

\footnotetext{
${ }^{18}$ PEREIRA, Caio Mário da Silva. Op. cit., p.40.
} 
de uma ação de resolução do contrato, em razão do inadimplemento contratual na quitação do preço, com pedido de imissão na posse.

Em resumo, portanto, através dessa cláusula de constituto possessório, o adquirente obtém a posse plena do bem de forma derivada e negocial.

Por fim, a posse pode se transferir não apenas negocialmente quanto a aquisição de forma derivada, mas também ope legis como se denota do que estabelece os arts. 1.206 e 1.207, ambos do CC/2002.

Tais artigos regulam a sucessão possessória, que pode ser universal ou singular. A sucessão universal é a que decorre da morte (sucessão causa mortis) e a sucessão singular é a oriunda de ato entre vivos (sucessão inter vivos).

A posse pela sucessão se transfere com todas as suas características, inclusive tempo de posse que pode ser utilizado para fins de usucapião. $\mathrm{Na}$ sucessão causa mortis, se verifica que essa transmissão é obrigatória, ao passo que na sucessão inter vivos pode ser ou não, porquanto, na sucessão singular (art. 1.207, $2^{\mathrm{a}}$ parte, CC/2002), a união das posses para efeitos legais é apenas uma faculdade do sucessor, que terá esse alvedrio ${ }^{19}$.

Então, verbi gratia, se alguém tem uma posse com animus domini por 10 anos e a transfere, o novo possuidor poderá contar a sua posse com esse caráter acrescido do tempo de posse anterior, a fim de usucapir o bem e terá que ficar mais 5 anos nessa condição (soma das posses), para que se declare a usucapião do imóvel através da usucapião extraordinária.

\subsubsection{Interversão da Posse}

A interversão da posse é uma alteração da causa possessinis e está fundada nos termos do art. 1.203, CC/2002, in litteris:

Art. 1.203. Salvo prova em contrário, entende-se manter a posse o mesmo caráter com que foi adquirida ${ }^{20}$.

\footnotetext{
${ }^{19}$ PEREIRA, Caio Mário. Op. cit., p. 40-41.

${ }^{20}$ BRASIL. Código Civil. Op. cit.
} 
Gize-se que a posse, até que sobrevenha prova em contrário, mantém o caráter com que foi adquirida, porém constata-se que essa presunção é iuris tantum, uma vez que admite prova em contrário, sendo justamente essa que se consubstancia na interversão da posse.

Essa mudança na natureza da posse conhecida como interversão pode ser tanto unilateral, quanto bilateral, possuindo maior ruído na doutrina aquela.

A interversão bilateral é simples e se dá, por exemplo, quando um contrato de locação se transmuda em um contrato de comodato, mudando de forma consensual a natureza da posse, porque a posse que era exercida a título oneroso, em razão de contraprestações efetuadas pelo locatário, passa, com a alteração contratual, a ser exercida à título gracioso do proprietário que não exige esse ato de contrapartida pecuniária.

Agora, quanto a interversão unilateral, ela gera ruído na doutrina e nos tribunais ${ }^{21}$, porque o momento em que ela se corporifica é casuístico. Muitas das vezes, quando ocorre o fenômeno da interversão bilateral da posse, uma posse precária, portanto, injusta, que não produz efeitos, se transforma em uma posse ad usucapionem, ou seja, qualificada com \animus domini.

Um contrato de locação, ou mesmo de comodato, pode propiciar em algum momento em posse ad usucapionem? Nota-se que a sutileza do instituto pode se tornar um grande gerador de injustiças, seja combatendo o proprietário, seja obstaculizando o cumprimento da função social (no caso de não vislumbrar a sua configuração) $)^{22}$.

\footnotetext{
${ }^{21}$ PAIVA, Daniela Reetz de. Interversão do Caráter da Posse. Disponível em: <http://www.emerj.tjrj.jus.br/serieaperfeicoamentodemagistrados/paginas/series/16/direitosreais_42.pd f>. Acesso em 15 jan. 2018.

22 MARTINO, Jean de. Da possibilidade da posse precária ser usucapida. Disponível em $<$ https://jeandemartino.jusbrasil.com.br/artigos/111812290/da-possibilidade-da-posse-precaria-serusucapida>. Acesso em 18 jan. 2018.
} 
Mas cabe reflexão, até porque um locatário que se instala no imóvel e a partir de determinado momento o locador não lhe cobra mais, de modo que com o tempo aquele passe a responder pelo imóvel, quanto a taxas e impostos, seja reconhecido publicamente como se dono fosse e não tenha nenhuma forma de oposição ou resistência a sua posse, não pode ser ad eternum considerado locatário, porquanto em algum momento se configurou a interversão da posse, que passou, então, a ser exercida com animus domini.

Mas a grande discussão que não cessará é o ponto inicial da contagem desse prazo, dessa mudança de posse e isso dependerá de um exame detalhado e cuidadoso do julgador.

\subsubsection{Função social da posse}

Discorrer sobre função social é tocar num tema sensível que coloca frente à frente o proprietário que não cumpre função social e o possuidor que cumpre. É perquirir quem tem a melhor posse e por quais razões.

Em primeiro lugar, a posse não pode ser tutelada em razão da propriedade, porque senão se desvirtuaria a discussão desse instituto. A posse não pode ser somente a "exteriorização da propriedade", ela precisa ser mais do que isso.

Nesse sentido, cabe ao direito proteger situações jurídicas existenciais, para além das situações eminentemente patrimoniais, ainda mais no Brasil, com o estabelecimento da constituição "cidadã", que é rica no estabelecimento de direitos e garantias fundamentais, que culminou, também, por conseguinte, na formação do direito civil-constitucional. Destarte, a fim de tutelar as situações fático-jurídicas existenciais é que se apregoou a "funcionalização" da tutela das situações jurídicas patrimoniais.

Uma visão mais humanista, defendida por defensores da teoria social da posse, diz que o agasalho jurídico da posse deve acontecer pelo fato desta proporcionar o exercício de direitos fundamentais pelos seres humanos, pois é 
através da posse que se mora (teto para habitar), trabalha (prestação de serviços), alimenta (sobretudo no campesinato) ${ }^{23}$, tem segurança (área individualizada), tem lazer (aspectos da intimidade), ou seja, ela é uma grande impulsionadora dos direitos elencados no art. $6^{\circ}, \mathrm{CRFB} / 88$, que são os direitos sociais.

Além disso, a posse por ser um estado de fato sobre a coisa (apesar da opinião dos doutrinadores que a colocam como direito), surge, ou pode surgir, de um contato natural com a coisa. Não necessariamente ela advirá de um direito real ou obrigacional, cujas formas estão positivadas no Código Civil, mas também, ela poderá emergir simplesmente de um contato direto, efetivo e natural com a coisa, independentemente do enquadramento nas hipóteses legais pré-definidas ${ }^{24}$.

Fora isso, forçoso reconhecer que a posse é um instituto autônomo e independente da propriedade, posto que se assim não fosse, impossível seria tratar da função social, uma vez que a posse proprietária sempre prevaleceria, como já fora outrora, à época do Código Civil de 1916, que previa em seu artigo 505 a exceção de domínio ${ }^{25}$.

Adentrar à função social é também reconhecer a individualização dos terceiros não proprietários, que não podem e não devem ser considerados como

${ }^{23}$ COSTA, Samara Danitielle. A função social da posse. Disponível em <http://www.ambitojuridico.com.br/site/?n_link=revista_artigos_leitura\&artigo_id=12222>. Acesso em 20 fev. 2018.

${ }^{24}$ OLIVEIRA, Camila Alves et al. Teoria e aplicabilidade da função social da posse e da propriedade nos direitos reais enquanto instrumento de efetivação dos direitos fundamentais. <http://www.ambitojuridico.com.br/site/index.php?n_link=revista_artigos_leitura\&artigo_id=8411 >. Acesso em 20 fev. 2018 .

25 (1) GURJÃO, Víctor. Posse: conceito, teorias fundamentais e classificação. Disponível em $<$ https://victorgurjao.jusbrasil.com.br/artigos/207694906/posse-conceito-teorias-fundamentais-eclassificacao>. Acesso em 22 fev. 2018. 
uma coletividade uniforme, decorrente da oponibilidade da posse erga omnes e do dever geral de abstenção de todos para com a posse do proprietário ${ }^{26}$.

Considerar tais pessoas dessa forma é fazer uma análise perfunctória que dificulta o reconhecimento da interação de qualquer pessoa, nessa qualidade, para com a posse do bem, colocando, por conseguinte, a posição do proprietário como muito confortável, independentemente do cenário travado.

Mister se faz, por último, avaliar o bem jurídico objeto da posse, vez que a função social incidirá de forma distinta a depender do bem, sob análise.

Verbi gratia, a função social de um imóvel para fins de moradia é patente, em razão de todos os direitos e repercussões dessa posse, ao passo que a função social de um bem de consumo abundante como o vestuário é pouco, ou até mesmo irrelevante, pela falta de envergadura dos direitos que esse bem pode resguardar, já que não têm o condão de prejudicar a coletividade ${ }^{27}$.

\subsection{Propriedade}

\subsubsection{Conceito de propriedade}

Vista a posse e suas peculiaridades, adentra-se, por oportuno, no instituto da propriedade e seus desdobramentos.

De início, impossível fugir da conceituação de propriedade, que pode variar de doutrina à doutrina.

Dessa forma, Orlando Gomes conceituou a propriedade por três aspetos: (i) sintético, que nada mais é do que a submissão de uma coisa a alguém, (ii) analítico, que diz respeito aos poderes elencados no art. 1.228, CC/2002, quais seja, os direitos de usar, gozar, dispor e rever de quem injustamente a possua

\footnotetext{
${ }^{26}$ (2) Ibid.

27 ARAUJO, Wilclem de Lázari. A função social e os bens móveis. Disponível em <https://www.direitonet.com.br/artigos/exibir/7825/A-funcao-social-e-os-bens-moveis〉. Acesso em 25 fev. 2018.
} 
ou detenha, (iii) descritivo, que se revela no direito absoluto, perpétuo, complexo e exclusivo que aprisiona a coisa a vontade da pessoa ${ }^{28}$.

Por outro lado, Cristiano Chaves Farias e Nelson Rosenvald a definem como uma relação jurídica complexa entre o titular da coisa e toda a coletividade de pessoas ${ }^{29}$.

Por fim, Caio Mário da Silva Pereira, assim conceituou:

"Fixando a noção em termos analíticos, e mais sucintos, dizemos, como tantos outros, que a propriedade é o direito de usar, gozar e dispor da coisa, e reivindicá-la de quem injustamente a detenha" ${ }^{30}$.

Como visto, a propriedade se traduz de uma forma singular para cada um dos juristas, parecendo esta última mais técnica do ponto de vista do que o legislador brasileiro estabeleceu.

$\mathrm{Na}$ verdade, da análise do Código Civil se verifica que o conceito de propriedade não está positivado, mas o conceito de proprietário sim, está.

Conforme o art. 1.228, CC/2002, o proprietário é aquele que tem o direito de usar, gozar, dispor e reaver a coisa de quem a possua ou detenha de maneira injusta, logo, se, para o diploma civil, esse é o conceito de proprietário, a propriedade, tecnicamente falando, não poderia ser nada diferente da união desses direitos inerentes ao proprietário, como bem lançou Caio Mário da Silva Pereira. Com toda a modéstia que cabe, o referido conceito se amolda perfeitamente ao conceito de proprietário estabelecido no código civil brasileiro.

\subsubsection{Estrutura do direito de propriedade}

\footnotetext{
${ }^{28}$ GOMES, Orlando. Direitos reais.18. ed. Atual. e notas de Humberto Theodoro Junior. Rio de Janeiro: Forense, 2002. p. 109.

${ }^{29}$ FARIAS, Cristiano Chaves; ROSENVALD, Nelson. Curso de Direito Civil: Direitos Reais. v. 5. $8^{\mathrm{a}}$ ed. Revista, ampliada e atualizada. Salvador: JusPodvim, 2012. p. 263.

${ }^{30}$ PEREIRA, Caio Mário da Silva. Op. cit., p. 39.
} 
A propriedade é o direito real por excelência, porquanto outros direitos reais possuem o condão de gerar a propriedade, como o direito de superfície que se subdivide em duas novas propriedades, a propriedade do solo e a propriedade da superfície, assim como o direito de laje, que se desdobra na propriedade da laje (propriedade lajeária) e a propriedade que sobeja, que fez nascer essa laje.

Esse instituto tem uma estrutura econômica, que está prevista no art. 1.228 , caput, $1^{\mathrm{a}}$ parte, $\mathrm{CC} / 2002$, ou seja, é pautada nos poderes de usar (ius utendi), gozar (ius fruendi) e dispor da coisa (ius abutendi). E essa é uma estrutura econômica, em razão do proprietário, por meio do exercício desses poderes, poder dar, com liberdade, a destinação que melhor lhe aprouver a coisa (obedecidos os possíveis limites legais).

Noutro giro, a propriedade também tem uma face jurídica, preconizada pelo $2^{\text {a }}$ parte do mesmo artigo supracitado, que se revela no poder de reivindicar a coisa, isto é, está relacionada a relação do proprietário com terceiros não proprietários. É através desse poder que o proprietário reivindica a coisa e a persegue de quem injustamente a possua, onde quer que seja (pensando também em propriedade de coisa móvel) ${ }^{31}$.

\subsubsection{Características da propriedade}

A propriedade antes de mais nada é um direito real pleno, pelos poderes dado ao proprietário, anteriormente vistos quando se tratou do conceito e da estrutura da propriedade. Ainda assim, essa plenitude não é absoluta, já que existem obstáculos legais a esse direito, fincados pela constituição federal, pelo código civil e pela legislação extravagante.

Um desses limites, por exemplo, é o direito de vizinhança e todas as suas variáveis, que podem reprimir o exercício da propriedade limitando o

\footnotetext{
${ }^{31}$ FERREIRA, Damares. O aspecto funcional da propriedade urbana na Constituição Federal de 1988. Disponível em $<$ http://www.ambitojuridico.com.br/site/index.php?n_link=revista_artigos_leitura\&artigo_id=4053>. Acesso em 02 mar. 2018.
} 
direito de construir, o espaçamento entre prédios, o direito de murar, o uso anormal da propriedade, o abuso das servidões de vista, luz e passagem, dentre outros.

Ainda nessa discussão, a função social não é considerada um limite ao exercício da propriedade, uma vez que ela acarretará na modificação da própria estrutura do direito de propriedade, fazendo parte, assim, dela ${ }^{32}$.

Outra característica da propriedade é a sua exclusividade, uma vez que, em regra, ela tem a titularidade de uma só pessoa. Essa exclusividade, no entanto, é relativa e pode ser mitigada. Tanto é assim que, hodiernamente, cada vez mais, se vê as co-propriedades, instrumentalizadas no instituto do condomínio.

Seguindo adiante, a propriedade também é dotada de elasticidade, na medida em que o proprietário pode exercer os seus poderes dominiais na sua integralidade ou não, ou dizendo de outro modo, pode ceder alguns desses direitos a uma terceira pessoa que será qualificada como possuidor, como já visto ao longo dessas linhas.

A propriedade, ainda neste tema, é um instituto provido de perpetuidade, de modo que a propriedade não se extingue com o tempo, salvo na hipótese da propriedade resolúvel, que se extingue com a implementação do encargo, termo ou condição.

Por tal característica imediatamente citada é que, infelizmente, o não uso acaba sendo um exercício da propriedade também, o que, em última ratio, pode levar a uma especulação imobiliária exorbitante pela escassez de bens imóveis.

Como meio coercitivo, há o Estatuto da cidade, que regula o uso do solo urbano - regulamenta o capítulo da política urbana da constituição da república

\footnotetext{
${ }^{32} \mathrm{MOESCH}$, Frederico Fernandes. O princípio da função social da propriedade e sua eficácia. Revista Jus Navigandi, ISSN 1518-4862, Teresina, ano 10, n. 880, 30 nov. $2005 . \quad$ Disponível em: <https://jus.com.br/artigos/7645>. Acesso em: 04 mar. 2018.
} 
(capítulo II - arts. 182 e 183), notadamente o $\S 4^{\circ}$, do art. 182, CRFB/1988 tendo, para tal fim, instrumentos de coerção para obrigar o proprietário a usar o bem, a dar alguma destinação específica a ele, como, verbi gratia, o IPTU progressivo, a desapropriação para interesse social e a edificação compulsória.

Prosseguindo, a aderência também é uma característica intrínseca à propriedade, já que a propriedade acompanha a coisa, independentemente de contato físico e efetivo com a coisa. Assim, poderá o proprietário estar a mil léguas de sua propriedade ou a dois passos, que será proprietário na sua inteireza da mesma forma.

Finalmente, a oponibilidade erga omnes também é uma característica concernente ao direito de propriedade, visto que o proprietário pode exigir o dever geral de abstenção quanto a violação da propriedade a toda a coletividade. Dentro desse aspecto, a função social, como já tratada outrora, vem para, dentre outras coisas, individualizar esses terceiros não proprietários, a fim de que haja uma relação mais direta entre cada um, singularmente, e o proprietário do bem, titularizado como tal.

Ademais, como não podia deixar de esclarecer, a função social vem para, nessa nova toada constitucional brasileira, moldar a estrutura da propriedade como um todo e interferir de certa forma em todas essas características supramencionadas. ${ }^{33}$

\subsubsection{Formas de aquisição da propriedade}

A aquisição da propriedade pode ser originária, quando ninguém ainda tenha se apossado dela, ou, explanando de outra forma, a que se adquire sem que haja uma transmissão de outrem, seja voluntária, seja involuntária, que

\footnotetext{
${ }^{33}$ ITO, Michel; ITO, Lilian Cavalieri. Da propriedade: conceituação, poderes e características. Boletim Jurídico, Uberaba/MG, a. 13, no 1509 . Disponível em: <https://www.boletimjuridico.com.br/doutrina/artigo/4480/da-propriedade-conceituacao-poderescaracteristicas> Acesso em: 09 mar. 2018.
} 
resulta numa propriedade sem relação causal com a situação jurídica anterior da coisa (res nullis), ${ }^{34}$ ou derivada, quando decorrente de uma relação com o seu atual dono, em que este transfere o direito proprietário a outrem ${ }^{35}$.

Segundo o Código Civil, se adquire a propriedade móvel pelos seguintes institutos: usucapião, ocupação, achado ao tesouro, tradição, especificação, confusão, comissão, adjunção.

Agora, a propriedade imóvel pode ser conquistada pelos instrumentos, a seguir: usucapião, aquisição pelo registro, acessão (ilhas, aluvião, avulsão, álveo abandonado e construções e plantações).

Serão analisados infra as formas de aquisição dos bens imóveis em seus pormenores, especialmente a usucapião e o registro que dizem respeito ao tema do presente trabalho.

\subsubsection{Perda da propriedade}

Os arts. 1.275 e 1.276 , ambos do CC/2002, versam sobre a perda da propriedade e muito embora caiba ao art. 1.275, CC/2002 elencar as hipóteses de perda da propriedade que são: (i) alienação, (ii) renúncia, (iii) abandono, (iv) perecimento da coisa e (v) desapropriação.

Destaca-se que este rol é meramente exemplificativo.

Isso porque, a redação é pedagógica ao dizer que essas são as formas pelas quais se perde a propriedade, mas existem outras consideradas no corpo do código, sendo algumas bem comuns, por sinal, como a evicção, o regime de bens (na comunhão universal de bens, o titular por inteiro do seu patrimônio passa a sê-lo em compartilhamento com o seu cônjuge, ou, pode-se dizer que perde o direito sobre metade deste acervo) e ainda mais a usucapião.

\footnotetext{
${ }^{34}$ (1) PEREIRA, Caio Mário da Silva. Op. cit., p. 97.

35 (2) Ibid. p. 98.
} 
A usucapião, bom destrinchar, ao mesmo tempo que é modo de aquisição da propriedade para um, é em igual tempo, a perda desse direito por outrem (o até então proprietário).

Em breves palavras, a alienação é um negócio jurídico bilateral, em que certa pessoa transfere a propriedade, sobre a qual se assenhorava, para outrem, de modo que este passe a ser o novo proprietário. Nela, imprescindível a manifestação de vontade de ambas as partes, para que se repute um negócio jurídico válido (bilateralidade dos contratos), contudo, dispensável a criação de obrigação para ambas as partes, podendo, portanto, apenas uma delas ter esse ônus (alienação gratuita, como na hipótese de doação). Ainda assim, em se tratando de bens imóveis, além disso, mister se faz também a realização do registro para que se opere a transmissão do bem, por este ser um requisito formal exigível em lei.

A renúncia é um ato unilateral solene, exercitável de forma expressa, em que o até então proprietário declara não querer mais ser o proprietário de determinada coisa. Esse se instrumentaliza com a escritura em cartório de notas e, por consequência, esse bem passa a ser vago, caso outra pessoa não assuma, em ato contínuo, a propriedade dele ${ }^{36}$.

O abandono, diferentemente da renúncia, é um ato material em que a pessoa demonstra de forma inequívoca não querer mais o ônus de ser proprietária de certo bem. Então, essa figura é muito mais, ou melhor, é um ato material, que se verifica no mundo dos fatos e não um ato jurídico, como é a renúncia. O legislador estabeleceu critérios no art. 1.276, CC/2002 do abandono de imóveis, por este ser mais delicado do ponto de vista da utilidade da coisa para outrem, sendo, em última análise, arrecada pelos entes públicos (município ou Distrito Federal se bem urbano, União Federal se bem rural - art. 1.276 e $\left.\$ 1^{\circ}, \mathrm{CC} / 2002\right)$.

\footnotetext{
${ }^{36}$ (3) Ibid p. 200.
} 
Analisando detidamente o disposto no art. 1.276, $\S 2^{\circ}, \mathrm{CC} / 2002$, constata-se que o abandono para se configurar necessita: (i) negligência do proprietário, de modo que não exerça nenhum dos poderes a ele conferidos pelo art. 1.228, CC/2002, (ii) cumulativamente, deixe de arcar com os ônus fiscais do bem ${ }^{37}$. A propriedade que sobre ela não recaia nenhum dos poderes a ela inerentes, nem mesmo cumpra as exigências legais fiscais, não pode ser vista como uma propriedade incólume ${ }^{38}$, muito pelo contrário, deve ser considerada como abandonada, porque se assim não fosse, difícil seria rotular em qualquer circunstância esse instituto jurídico, fazendo, por conseguinte, dele letra morta na legislação.

O perecimento, outra forma de perda da propriedade, é simplesmente o esgotamento da coisa, ou seja, o bem deixa de existir e assim sendo, não subsistirá o direito do proprietário, uma vez que impossível ser dono de algo inexistente.

A desapropriação já se apresenta como um instituto mais rico, na medida em que comporta a desapropriação judicial privada, previstas nos $\S \S^{\circ}$ e $5^{\circ}$, do art. 1.228, CC/2002. Se assemelha a usucapião coletiva, mas não se equipara, em razão do cunho indenizatório que a consubstancia, além de ser um modo de aquisição derivada da propriedade. A desapropriação é privada por não envolver a intervenção estatal e se opera com a prolação de sentença judicial.

\footnotetext{
37 PEREA, Nayara Moreno. <https://jus.com.br/artigos/42784/a-perda-da-propriedade-urbana-peloabandono-aliado-ao-nao-pagamento-dos-tributos-e-o-papel-dos-municipiosA perda da propriedade urbana pelo abandono aliado ao não pagamento dos tributos e o papel dos Municípios>. Acesso em 10 mar. 2018.

38 (2) Id., A perda da propriedade urbana pelo abandono aliado ao não pagamento dos tributos e o papel dos municípios <https://nayaraperea.jusbrasil.com.br/artigos/247744872/a-perda-dapropriedade-urbana-pelo-abandono-aliado-ao-nao-pagamento-dos-tributos-e-o-papel-dos-municipios $>$. Acesso em 10 mar. 2018.
} 
Esse instituto pode ser usado como meio de defesa nas ações de reintegração de posse com imissão na posse movidas pelos proprietários em casos onde haja uma afixação consolidada de pessoas em determinada área.

A desapropriação clássica é aquela promovida pelo estado visando o interesse público, seja econômico, seja social, onde este interesse deve ser prestigiado frente ao interesse particular. Nela, o Estado paga uma prévia e justa indenização ao proprietário, ao passo que na desapropriação privada, quem paga são os próprios ocupantes, que possuem o intuito de na área permanecer (caráter social de permanência em observância concreta da função social).

Contudo, o aperfeiçoamento de tal instituto por um lado concretiza a função social, atendendo ao fim colimado pelo texto constitucional, mas por outro pode dar ensejo, se difundido, às invasões de terras arbitrárias ao arrepio da legislação. Então, a aplicação desse instituto deve ser não conservadora, mas sim cautelosa e casuística pelos tribunais que dela se valham. ${ }^{39}$

Em que pese a indenização dos particulares (ocupantes) ao particular (proprietário), deve-se ser realista e perceber que na maioria das vezes esses ocupantes que objetivam a aplicação do instituto são pessoas humildes, pobres, sem recursos e aporte financeiro necessários a devida indenização ao proprietário que descumpriu a função social. Este foi o grande culpado em deixar a situação se lastrear e consolidar por mera negligência, então, por que não os aparelhos públicos patrocinarem essa indenização? É um tema vasto, que renderia outro trabalho monográfico, mas em primeira análise, seria uma boa solução, podendo, por meio deste instituto, o ente municipal ou federal promover a política pública de interesse social posta na carta constitucional.

\footnotetext{
${ }^{39}$ SANTOS, Frederico Fernandes dos. Desapropriação por iniciativa privada. In: Âmbito Jurídico, Rio Grande, XIX, n. 147, abr 2016. Disponível em: <http://www.ambitojuridico.com.br/site/index.php?n_link=revista_artigos_leitura\&artigo_id=16609\&revista_caderno=7>. Acesso em 11 mar. 2018.
} 


\subsubsection{Função social da propriedade}

A CRFB/1988 trata em seu art. 50, XXIII da função social da propriedade, reconhecendo, indiretamente, a existência de dois centros merecedores de tutela, quais sejam, a situação jurídica proprietária e a situação jurídica dos terceiros não proprietários, que podem, ou não, ser possuidores do bem controvertido ${ }^{40}$.

Na visão clássica, como já esposado, o proprietário se relaciona como a coletividade em geral, exigindo desta o dever geral de abstenção para com a sua propriedade.

$\mathrm{O}$ art. $5^{\circ}, \mathrm{XXIII}, \mathrm{CRFB} / 1988$ tem como destinatários os terceiros não proprietários, porque essa norma dá concretude a esse centro de interesse, que antes era visto de forma abstrata. Ela permite a individualização desses terceiros por meio do cumprimento da função social, o que pode, no sentido bom do termo, incomodar, a plenitude do proprietário. A função social estabelece uma relação dialética entre esses dois centros de interesse, fazendo com que os terceiros não proprietários exijam que o proprietário dê funcionalidade a coisa (compromete a estrutura jurídica do direito de propriedade). ${ }^{41}$

A propriedade, tida como um direito absoluto e perpétuo, diante da nova praxe civil-constitucional, passa a ser moldada pela nova realidade social, ou explanando de outra forma, a propriedade não se satisfaz mais somente atendendo ao direito do proprietário, mas esta deve resguardar os interesses de toda a coletividade, não podendo lesá-la.

\footnotetext{
${ }^{40}$ (1) NETTO, Roberta de Freitas. Propriedade E Domínio: Uma Releitura À Luz Do Princípio Da Função Social.

Disponível

em <https://bdjur.stj.jus.br/jspui/bitstream/2011/18445/Propriedade_e_Dom\%C3\%ADnio.pdf〉. Acesso em 16 mar. 2018.
}

${ }^{41}$ (2) Ibid. 
A propriedade deve promover os interesses existenciais, para além dos patrimoniais, deve observar os interesses urbanos, culturais, históricos, ambientais, dentro outros, não podendo o proprietário ignorar tudo que está fora da sua propriedade a seu bel-prazer.

O cuidado que se tem que tomar é que o proprietário em última análise ainda é proprietário, então, não pode ele perder esse direito e viver em função dos outros. Não é isso que está a se tratar, o que se examina, por seu turno, é que a função social compatibiliza essa situação jurídica proprietária a todas as demandas existenciais citadas, num contexto em que estas não podem ser "esquecidas".

No meio rural, o art. 186, CRFB/1988 relaciona o cumprimento da função da propriedade rural ao trabalho na terra, ao meio ambiente, ao uso racional do solo. Já no meio urbano, o art. 182, $\S 2^{\circ}$ dispõe que a função social é cumprida, quando atende as exigências do plano diretor (exigível para cidades com mais de 20 mil habitantes), uma vez que cabe a este definir o que vem a ser função social em cada cidade (cada cidade tem a sua própria função social).

O plano diretor é uma lei municipal que tem a finalidade de estipular as políticas públicas urbanas que devem ser desenvolvidas em determinada localidade. Ele conta com a participação popular em sua elaboração e deve ser atualizado de $10 \mathrm{em} 10$ anos, por conta do dinamismo de desenvolvimento complexo da cidade (apesar dessa participação popular, essa ainda é pouco efetiva, vez que é meramente consultiva, não possuindo conteúdo decisório e deliberativo).

Outra questão a isso relacionada é como estabelecer critérios para a concretização da função social em cidades com menos de 20 mil habitantes? Não sendo rural, não sendo urbana com mais de 20 mil habitantes, a localidade fica num hiato problemático, que pode ser resolvido por aplicação de institutos analogicamente. Todavia, em que pese essa possibilidade, isso não deixa de ser 
um entrave a observância da função social, visto que ela já não é bem manejada, onde há regulamentação.

Verifica-se, atualmente, que o legislador quis privilegiar a posse com função social em detrimento da propriedade sem função.

Isso se evidencia por meio de algumas regras apresentadas por ele, como a desapropriação judicial privada (art. 1.228, $\S 4^{\circ}, \mathrm{CC} / 2002$ ), a redução do prazo na usucapião ordinária (art. 1.242, parágrafo único, CC/2002) e extraordinária (art. 1.238, parágrafo único, CC/2002) quando a posse é de cunho social, a abolição da exceção de domínio (art. 1.210, §2, $\mathrm{CC} / 2002$ ), que impede a alegação de propriedade em embate sobre posse, a acessão invertida (art. 1.255, parágrafo único, CC/2002), que privilegia quem construiu ou plantou, em certas circunstâncias, o abandono (art. 1.276, III, CC/2002).

Portanto, o proprietário deve funcionalizar a sua propriedade, a fim de que tenha seu direito em sua plenitude assegurado, já que, agora, existem mecanismos capazes de "afrontar" a propriedade desfuncionalizada. No entanto, compulsando a jurisprudência pátria, ainda há uma conservadorismo na utilização desses institutos.

E, uma última reflexão, diante do exposto, é solucionar o embate entre proprietário e possuidor que cumprem, ambos, a função social. Quem deve prevalecer? Por mais que a análise possa ser casuística e que a posse permita o exercício de direitos fundamentais, imperioso se faz reconhecer a segurança jurídica, bem como o direito fundamental a propriedade, eleita pelo constituinte como tal, de modo que se o proprietário cumprir a função social, não pode este, sob pena de violação de direito fundamental, de arbitrariedades, ser retirado da propriedade, porque a exerce da maneira necessária a sua proteção 


\section{Capítulo 2 - Usucapião, Ações Possessórias, Ministério Público e seus conceitos jurídicos}

\subsection{A usucapião}

\subsubsection{Conceito e fundamentação da usucapião}

A usucapião, como já alinhavado, é uma das formas de aquisição da propriedade, sendo instituto bastante a aquisição tanto dos bens móveis, quanto dos bens imóveis, assim como de outros direitos reais usucapíveis ${ }^{42}$, como as servidões, o usufruto, o domínio útil na enfiteuse, através do exercício de uma posse qualificada, que é a posse ad usucapionem.

Assim a definiu José Carlos de Moraes Salles:

Podemos conceituar a usucapião como a aquisição do domínio ou de um direito real sobre coisa alheia, mediante posse mansa e pacífica, durante o tempo estabelecido em $\mathrm{lei}^{43}$.

A usucapião é um modo, portanto, de aquisição da propriedade que se perfaz através de uma posse anterior, que é, como citado, a posse ad usucapionem, associada a um dado período de tempo, pela qual aquela perdurou.

Essa posse qualificada é uma posse que precisa, antes de mais nada, ser mansa e pacífica, ou seja, uma posse que não tenha oposição, na medida em que não seja contestada por outrem.

Além disso, tem que ser uma posse em caráter contínuo, ininterrupto, sob pena de macular o lapso temporal fixado em lei.

E, ainda, como não poderia deixar de ser, senão lógica não teria o instituto, uma posse exercitável com animus domini, já que, para usucapir, sine qua non se evidencia a intenção de ser dono.

\footnotetext{
42 (1) SALLES, José Carlos de Moraes. Usucapião de Bens Imóveis e Móveis. $6^{\mathrm{a}}$ ed. rev., ampl. e atual. de acordo com o Código Civil de 2002. São Paulo: Editora Revistas dos Tribunais, 2005.

${ }^{43}$ (2) Ibid. p. 48-49.
} 
Inclusive, não poderia deixar de mencionar, a posse com animus domini é o resquício da teoria subjetiva da posse de Savigny vista no 1.1.1 supra, uma vez que o legislador brasileiro prestigiou a teoria objetiva de Jhering, como também visto no mesmo sub-capítulo.

Neste diapasão, o locatário, o usufrutuário, o depositário, por exemplo, não podem usucapir um bem, pela inexistência de animus domini em sua posse. Denota-se que essa figura em momento algum, no exercício regular de suas atribuições possuem a finalidade de se apossar da coisa com a vontade de proprietário dela.

Avançando, a posse ad usucapionem deve ser exercida por um dado período de tempo, notadamente pelo tempo fixado em lei, visto que, por mais que a posse seja contemplada com o animus domini, se o requisito legal temporal não for atingido, impossível será a aquisição da propriedade por meio da usucapião.

Por fim, a posse, aqui tratada, precisa ser sobre um bem particular, na medida em que os bens públicos não passíveis de serem usucapidos, conforme o disposto no arts. $183, \S 3^{\circ}, 191$, parágrafo único, ambos da CRFB/1988 c/c art. $102, \mathrm{CC} / 2002^{44}$.

Dessa forma, caso um particular preencha todos os requisitos legais da usucapião urbana, que se verá infra, de um bem de natureza pública, ele não poderá usucapi-lo, necessitando colocar, no seu pleito judicial, o pedido de usucapião do domínio útil do imóvel.

Tanto é assim, que umas das funções da intimação das Fazendas no rito da usucapião é verificar o interesse dessas na ação e esse se constitui pela natureza do bem. Desse modo, quando o município, por exemplo, manifesta o seu interesse, ele solicita ao Juízo a intimação da parte autora na demanda de

\footnotetext{
${ }^{44}$ (3) Ibid. p. 83.
} 
usucapião, para que esta emende a inicial e restrinja o seu pedido inicial ao domínio útil do imóvel, se assim não procedeu desde o início.

Nesse último caso exemplificado, não se verifica o animus domini em momento algum, pela impossibilita jurídica imposta, tendo, por conseguinte, o animus de uso ou de algum outro direito real que se pretende usucapir.

Com efeito, não é demais mencionar algo já pincelado para fins de reforço, que é justamente o caráter originário da aquisição por usucapião, de modo que aquele que adquire a posse através deste instituto, em nada se relaciona juridicamente ao proprietário antecessor, uma vez que trata-se de propriedade originária e não derivada.

\subsubsection{Espécies de usucapião de bens imóveis}

Inicialmente, cabe pontuar que tratar-se-á da usucapião de bens imóveis, por esta estar intimamente relacionada ao tema sob análise, não havendo propósito, em si, em discorrer a respeito da usucapião de bens móveis.

\subsubsection{Usucapião extraordinária}

Isto posto, a primeira modalidade de usucapião disciplinada pelo código é a usucapião extraordinária, que permite a usucapião de bens em 15 (quinze) anos, dispensando o justo título e a boa-fé. Essa espécie não faz qualquer exigência de ocupação social, logo, pode se usucapir, independentemente da destinação dada a coisa (não precisa ser como fim de moradia pela ausência dessa).

A usucapião extraordinária está regrada no art. 1.238, CC/2002 e o parágrafo único estipula justamente a hipótese da posse com cunho social, na medida em que se a posse é utilizada com o intuito de moradia ou trabalho, o prazo da usucapião extraordinária se reduz a 10 anos.

\subsubsection{Usucapião ordinária}


Seguindo adiante, outra espécie de usucapião é a ordinária, prevista no art. 1.242, CC/2002, que exige a presença da boa-fé e justo título. A boa-fé é a subjetiva tratada supra em 1.1.1 e o justo título é o documento, um instrumento idôneo, que seria hábil a transferir a propriedade, mas em decorrência de algum vício, não a fez ${ }^{45}$.

Esse vício não pode ser no plano da existência do negócio jurídico, já que esse contaminaria o contrato em suas bases mais elementares, de modo que ele inexistiria.

Se, também esse vício for no plano da validade e torne o título nulo, ele não pode ser utilizado como justo título para fins de usucapião, dada a gravidade, que o torna insanável (art. 166, CC/2002).

Verbi gratia, se duas pessoas celebram um contrato de compra e venda por instrumento particular, desobedecem a forma prescrita em lei, logo esse contrato não poderá ser usado como justo título, visto que o negócio pactuado é nulo. Além disso, no presente exemplo, tal prática burlaria o fisco, uma vez que a ausência de publicidade na transmissão impediria o conhecimento da burocracia tributária, implicando, assim, na ausência de recolhimento de ITBI (imposto de transmissão de bens imóveis) de $2 \%$ sobre o valor do imóvel.

Dito isso, os vícios no título que não o impedem de ser considerado como justo título são os decorrentes de negócio jurídico anulável (art. 171, CC/2002), ou ineficaz, porquanto tais vícios atingem apenas a esfera dos interesses particulares.

À título de exemplo, um contrato de compra e venda celebrado por instrumento público não registrado por ausência da outorga uxória ou marital é um justo título para a usucapião ordinária, já que, se jamais sanado esse vício e cumprido todos os demais requisitos, poderá se usucapir o bem em tempo futuro (10 anos depois).

45 (4) Ibid. p. 126-128. 
De igual modo, a ineficácia que diz respeito aos elementos acidentais do negócio jurídico, quais sejam: (i) termo, (ii) encargo, (iii) condição e sendo, in casu, não realizado ou implementado, poderá, depois de preenchidos os demais requisitos legais pertinentes, usucapir pela espécie ordinária, uma vez que o documento de transferência será considerado um justo título para este fim.

O enunciado 86, CJF diz o óbvio ao explanar que o documento considerado como justo título não precisa estar devidamente registrado para ser tido como justo título. E é claro, porque se registrado estivesse, não se discutiria o justo título, porque a propriedade já estaria transferida ao novo dono, dispensando a regularização almejada.

Ainda na usucapião ordinária, o parágrafo único do art. 1.242, CC/2002 cuida da redução de prazo de 10 (dez) para 5 (cinco) anos, estabelecendo que para que haja a incidência deste benefício, deverá estar presente a boa-fé e o justo título oneroso, vedando a possibilidade de um justo título oriundo de um contrato gracioso, como a doação.

O justo título pode ser proveniente tanto de uma aquisição à título oneroso (compra e venda ou dação em pagamento), quanto a título gratuito, no entanto, para que se aplique a usucapião ordinária com redução de prazo, imperioso se faz a onerosidade do título.

Além da boa-fé e do justo título oneroso, o título tem que ter sido registrado e posteriormente cancelado após 5 (cinco) anos do registro que havia sido validado. Portanto, para que incida essa regra, é preciso que haja o cancelamento do título que transferiu a propriedade, depois de decorridos 5 (cinco) anos.

Por fim, a posse tem que ter caráter social, voltada a destinação para moradia ou trabalho.

Em resumo, enfim, verifica-se que a usucapião ordinária com redução de prazo se instrumentaliza quando: (i) tenha boa-fé, (ii) haja justo título oneroso, (iii) o título foi registrado e cancelado após 5 (cinco) anos, (iv) a 
posse tenha finalidade de moradia ou tenham sido realizados investimentos sociais e econômicos. ${ }^{46}$

Nota-se, então, que a alegação de usucapião ordinária com redução de prazo é restrita, pelo fato dos vários requisitos que lhe são exigidos. Entretanto, pode ser uma boa estratégia de defesa, caso alguém, após esse cancelamento reivindique a propriedade do bem. Essa foi uma boa solução dada pelo legislador para a defesa da posse e, em tal circunstância, o requerido pedirá ao juiz da causa a declaração da propriedade pela usucapião e não pelo registro, que fora cancelado.

\subsubsection{Usucapião especial rural}

Prosseguindo, outra espécie de usucapião de bens imóveis é a usucapião especial rural, que vem positivada no art. 1.239, CC/2002, apresentando-se como uma modalidade de forte cunho social como se verá a seguir.

Como primeiro pressuposto, tem-se que o imóvel tem que se situar em área rural, sendo que esta é o que não é definido como área urbana. Cabe ao município definir a área urbana, porque a constituição diz que este ente federativo é responsável pela política urbana, ao passo que a política rural é desenvolvida pela União Federal. Assim, definida a área urbana pelo município, o que sobeja é considerado área rural.

Além da necessidade da área ser rural, existe uma limitação territorial da área que se pretende usucapir, que é de 50 (cinquenta) hectares, que é o equivalente a 50 (cinquenta) mil metros quadrados. Prima facie, parece ser uma porção de terra extremamente extensa, mas tendo e vista a lógica do campo, impossível comparar o tamanho da área rural à área urbana, uma vez que em zona rural se desenvolve atividades como agricultura (precisa de grande espaço para cultivo), pecuária (criação de gado), dentre outras atividades nessa toada.

${ }^{46}$ (5) Ibid. p. 144-145. 
Em que pese a área ser extensa frente a um latifúndio, trata-se de área de porte pequeno. Por consequência lógica, em razão dessa limitação, um latifúndio jamais poderia ser adquirido por inteiro por usucapião e agiu bem, ao que parece, o legislador.

Ainda assim, por mais utópica que seja a discussão, pela usucapião extraordinária ou até mesmo ordinária, um latifúndio poder-se-ia ser usucapido.

Além de ser em área rural, ter o limite de 50 (cinquenta) hectares, o possuidor que pretende usucapir o bem não pode ter outro imóvel em seu nome, seja ele rural, seja ele urbano. Essa limitação imobiliária demonstra o cunho social da usucapião especial rural.

Ademais, tem que também ser uma área com destinação à moradia, bem como ser produtiva, logo, não basta morar, não basta tornar o bem produtivo, tem que morar e tornar a propriedade produtiva, cumulativamente.

A produtividade não tem regulamentação legal, então avaliar se a propriedade é ou não produtiva, dependerá de uma análise in concreto, o que muitas das vezes pode se tornar difícil.

Por fim, ainda lhe é exigido o prazo de 5 anos ininterruptos, ou seja, a posse mansa, pacífica, contínua e com animus domini por este período. Perceba-se que não se exige justo título, nem boa-fé à hipótese.

\subsubsection{Usucapião especial urbana}

Em outra face, existe também a usucapião especial urbana, regrada no art. 1240, CC/2002. Para se enquadrar nessa espécie, antes de mais nada como o nome indica, o imóvel deve se situar em área urbana, que é definida pelo município.

Aqui, também inexigível a boa-fé e o justo título, mas de igual modo, o imóvel tem que ser utilizado com o fim de moradia, fazendo sentido também, uma destinação mista, na medida em que, na realidade brasileira, o trabalho 
doméstico informal é um fato. Ainda assim, a destinação preponderante tem que ser a moradia, sob pena de um viés econômico desnaturar o instituto.

De igual jeito a usucapião especial rural, em razão desse cunho social intrínseco exacerbado, o possuidor não pode ter, em nome próprio, outro imóvel, porque, também perder-se-ia a razão social do instituto.

Como a finalidade é de moradia, há obstáculo a usucapião de terreno, vez que um terreno não se presta a moradia em sentido direto e se esse é a finalidade da espécie, não faria sentido garantir moradia, sem a fornecê-la. Aqui, a discussão vai muito além do possuidor poder construir ou não uma casa para si, vai para a linha de: como o possuidor ao longo de 5 anos exerce com animus domini a posse de um terreno urbano com o intuito de se instalar e morar? Se por um lado realizou uma obra e edificou uma casa, não há mais que se falar em usucapir terreno, se por outro, não construiu, infactível pensar que exerceu posse com animus domini na localidade disputada.

Também aqui existe limite de metragem, porquanto o imóvel poderá ter o tamanho máximo de $250 \mathrm{~m}^{2}$ (duzentos e cinquenta metros quadrados), apesar do terreno onde se situa o imóvel poder ser em área maior.

A situação é muito simples, um condomínio de apartamento tem, por exemplo, a área do prédio edificado, com várias unidades autônomas e uma área comum externa. Se somar a área do edifício com a área comum (garagem, portaria, rua interna, área de lazer e etc.), é óbvio que a área será muito maior que $250 \mathrm{~m}^{2}$, mas o apartamento em si, e incomum não é, poderá ter área inferior, até bem inferior a $250 \mathrm{~m}^{2}$, sobretudo a depender da área, já que onde a especulação imobiliária é grande, a tendência são de unidades autônomas bem reduzidas.

A usucapião urbana, além da regulação no código civil, como colocado, também tem previsão constitucional no art. $183, \mathrm{CRFB} / 1988$ e no art. $9^{\circ}$, do Estatuto da Cidade. 


\subsubsection{Usucapião por abandono do lar}

$\mathrm{O}$ art. 1240-A, CC/2002 trouxe uma nova modalidade de usucapião, que é a usucapião por abandono do $1 \mathrm{lr}^{47}$, também conhecida como usucapião familiar ou especialíssima ${ }^{48}$. Ela tem os mesmos requisitos da usucapião especial urbana, mas se presta ao cônjuge ou companheiro usucapir a meação do outro.

O legislador criou essa espécie para proteger a entidade familiar, que segue residindo no imóvel do ente que o abandonou. Como leciona Caio Mário, não pode se dar uma interpretação restritiva ao instituto, no sentido de que apenas se o animus abandonandi se configurar, isto é, se a vontade deliberada de abandonar a família se perfizer. Se essa fosse a interpretação, o instituto perderia boa parte de sua finalidade, até porque dificilmente se provaria essa intenção do abandonando. Desse modo, como o objetivo é tutelar a entidade familiar, a exigência de não possuir outro imóvel também deve ser ampliativamente interpretado, na medida em que não se deve ter outro imóvel com cunho residencial, mas comercial poderá ter, porque isso, de certa forma, não interferiria na morada da família. ${ }^{49}$

Nessa hipótese o prazo para a declaração de usucapião é de 2 (dois) anos, sendo este o menor prazo estabelecido pelo legislador pátrio, quanto ao tema.

\subsubsection{Usucapião coletiva}

\footnotetext{
${ }^{47}$ TARTUCE, Flávio. A Usucapião especial urbana por abandono do lar conjugal. Disponível em <https://flaviotartuce.jusbrasil.com.br/artigos/121820005/a-usucapiao-especial-urbana-por-abandonodo-lar-conjugal>. Acesso em 16 mar. 2018.

48 (1) PEREIRA, Caio Mário Da Silva. Op. cit. p. 132.

49 (2) Ibid. p. 133.
} 
Enfim, existe ainda, e não menos importante, a usucapião coletiva, positivada no art. 10, do Estatuto da Cidade. Essa espécie pode ser utilizada quando se torna extremamente dificultoso individualizar as ocupações ${ }^{50}$.

Os ocupantes pleitearão a usucapião de toda área e em caso de procedência, formarão um condomínio, de modo que cada proprietário se torne proprietário de uma fração ideal do imóvel usucapido.

Posteriormente, esse condomínio poderá ser desfeito através de ações de divisão e demarcação de terras, ou até mesmo pela via administrativa junto a municipalidade, responsável pelo parcelamento do solo urbano.

São raras as hipóteses de usucapião coletiva, porque a tendência no Brasil é de individualizar as demandas.

\subsection{As ações possessórias}

\subsubsection{Disposições gerais}

As ações possessórias lato sensu estão reguladas no Novo Código de Processo Civil entre os arts. 554 e 568, CPC/2015 e podem debater dois juízos, o possessório e o petitório.

As ações que discutem juízo possessório são as ações possessórias em sentido estrito, ou também conhecidas como ações possessórias puras, ao passo que as ações que discutem juízo petitório são ações possessórias impuras, ou, para alguns, nem ação possessória são, já que debatem propriedade e não posse.

Enquanto que na ação possessória pura a causa de pedir é o direito de posse, a ação possessória impura tem como causa de pedir o direito de propriedade.

\footnotetext{
${ }^{50}$ OLIMPIO, Daniel Lobo. Usucapião Coletivo. Disponível em <http://www.egov.ufsc.br/portal/sites/default/files/anexos/9215-9214-1-PB.pdf>. Acesso em 27 abr. 2018.
} 
Em que pese a causa de pedir, a ação petitória poderá ter como pedido além da propriedade, a posse também, na medida em que a controvérsia se instale no direito de posse fundado na propriedade.

Quanto a este ponto, a súmula 487, STF é clara ao dizer que a posse será dada a quem for o dono se a discussão for a posse fundada no domínio (não pode alegar propriedade em defesa de ação possessória pura).

Nem sempre quem manejará a ação possessória será o proprietário, uma vez que o possuidor, na sua qualidade, poderá defender a sua posse, até mesmo contra o proprietário que a moleste de maneira injustificada.

Agora, em relação a usucapião, a súmula 237, STF estabelece que a usucapião pode ser alegada em defesa, desde que a ação seja de juízo petitório, porque se possessório for (ação possessória pura), haverá óbice a isso.

Noutro giro, uma regra importante trazida pelo art. 554, CPC/2015, que inaugura a regulação da matéria, é que o ajuizamento de ação errada não obstará o seu conhecimento se os requisitos da ação que se pretendia, e era adequada ao caso, estiverem presentes, o que evidencia o objetivo do legislador de dar celeridade a uma discussão tão cara.

Por fim, a lei 13.105/2015 trouxe uma regra nova quanto a coisa julgada das ações possessórias nos $\S \S 1^{\circ}$ e $2^{\circ}$ do art. 503. O caput traz a regra geral que a questão principal em ações possessórias faz coisa julgada, não podendo, portanto, ser futuramente rediscutida entre as partes. Já os referidos parágrafos inovam e dizem que haverá coisa julgada independentemente de pedido da questão prejudicial também, se: (i) da resolução da questão prejudicial depender o julgamento da questão principal, (ii) se tiver ocorrido contraditório prévio e efetivo, não sendo caso de revelia, (iii) o juízo tiver competência para resolver a questão prejudicial como se principal, em razão da matéria e da pessoa.

\subsubsection{Ação de manutenção de posse}


A ação de manutenção de posse visa proteger a posse em face da turbação, que é uma perda parcial da posse, ou seja, o dano já se iniciou. Aqui, o interdito se verifica pela moléstia de fato, quando se vê a turbação fática ou de direito, quando se realiza por via judicial ou administrativa, como, por exemplo, um anúncio de venda pública da coisa possuída (turbação de direito). ${ }^{51}$

Se a moléstia for recente, datada de menos de ano e dia, será uma ação de força nova, que seguirá o procedimento especial, ao passo que se datar de mais de ano e dia será de força de força velha, incidindo o procedimento comum do processo de conhecimento.

Quanto a este último ponto tratado há divergência doutrinária quando ao início da contagem de prazo em turbações plurais, que influirá no procedimento a ser adotado e melhor solução não há, senão dividir: (i) se os atos turbativos tem nexo de causalidade, contar-se-á o prazo para manejo de ação com rito especial, a partir do último ato lesivo, (ii) se inexiste correlação, serão atos turbativos autônomos, logo, cada um tem contagem autônoma, (iii) na sequência de atos de moléstia, o que importe privação da posse deve ser considerado para contagem do prazo, vez que a discussão diz respeito a manutenção da posse. ${ }^{52}$

O juiz, nesse caso, expedirá mandado de manutenção de posse.

\subsubsection{Ação de reintegração de posse}

$\mathrm{Na}$ ação de reintegração de posse, o vício é o esbulho, que é a perda integral da posse, cabendo ao juízo, ao final, se procedente o pedido, expedir o mandado de reintegração de posse.

Também existe a possibilidade nesta ação do rito ser especial ou comum, a depender se a ação é de força nova ou velha, pelas mesmas razões

\footnotetext{
51 (1) PEREIRA, Caio Mário da Silva. Op. cit. p. 55.

${ }^{52}$ (2) Ibid. p. 57
} 
esposadas, quando se tratou da ação de manutenção de posse, isto é, a data do esbulho, no caso.

Para que alguém possa se valer dessa ação, o proponente tem que ter exercido posse e o esbulho tem que ter sido praticado, privando-o da posse da coisa. Se a coisa for privada, porém, por justa causa, não restará caracterizado o esbulho. ${ }^{53}$

Aqui, igualmente, além de poder ser movida contra um terceiro pelo possuidor direto, ele poderá se valer desse meio processual para se resguardar frente ao possuidor indireto, não podendo este alegar, em defesa, juízo petitório, porquanto o debate é quanto a posse. ${ }^{54}$

\subsubsection{Interdito proibitório}

$\mathrm{Na}$ ação de interdito possessório, ao contrário das ações de manutenção e reintegração de posse, ainda não houve a moléstia à posse, seja total, seja parcial, ou seja, ainda se está diante de uma ameaça de turbação ou esbulho.

Por ser uma ação de caráter preventivo, a moléstia a que se previne tem que ser iminente, ou melhor, a ameaça tem que concreta, real e atual, superando, portanto, um mero temor.

Então, caberá ao autor do interdito proibitório ter o fundado receio da violência a ser praticada, fazendo prova da sua posse, da ameaça a que se quer proteger e da probabilidade desta vir a acontecer. ${ }^{55}$

\subsubsection{Ação de dano infecto}

A ação de dano infecto também é uma ação preventiva e é adequada a hipótese em que o vizinho em demolição ou vício de construção traga prejuízos. ${ }^{56}$

\footnotetext{
53 (3) Ibid. p. 57.

54 (4) Ibid. p. 58.

${ }^{55}$ (5) Ibid. p. 59
} 
Verbi gratia, caberá a presente ação se o proprietário do terreno lindeiro edificar uma construção de engenharia duvidosa, assim, como se, para tanto, precisar demolir o mausoléu que lá estiver. Ou, mais comum ainda, um problema de excesso de ruído ${ }^{57}$ ou acumulo de lixo em um apartamento, comprometendo o bom convívio social entre os condôminos (como visto no processo de $n^{\circ}$ 0288601-34.2016.8.19.0001, que tramita na $3^{\mathrm{a}}$ Vara Cível da Comarca da Capital do Estado do Rio de Janeiro, em que um apartamento, por falta de limpeza, gerou excesso de lixo, bem como proliferação de baratas que adentraram aos imóveis vizinhos, necessitando, por tal razão, que estes vedassem as passagens das portas de acesso dos apartamentos para a manutenção da incolumidade de suas residências).

\subsubsection{Ação de nunciação de obra nova}

A ação de nunciação de obra nova tem como finalidade obstaculizar o levantamento de obra pelo vizinho realizada nos limites das linhas lindeiras dele. Isso porque, se a obra for concluída pode resultar em turbação ${ }^{58}$.

Ela tem natureza possessória e cominatória, porquanto, busca a fixação de multa se os trabalhos da obra recomeçarem, a partir da determinação para cessá-los.

Nota-se que para o cabimento da ação, além da posse, da realização da obra pelo vizinho em seus limites, da moléstia que esse engenho venha a gerar a posse, é necessário também que a obra seja nova, no sentido de estar sendo levantada, porque uma vez concluída, não caberá mais essa medida, cabendo, por oportuno, ação demolitória. ${ }^{59}$

\footnotetext{
56 (1) TARTUCE, Flávio. Op. cit., p. 60.

57 (2) Ibid. p. 60.

58 (1) PEREIRA, Caio Mário da Silva. Op. cit., 59.

${ }^{59}$ (2) Ibid. p. 60.
} 


\subsubsection{Ação de imissão na posse}

A ação de imissão na posse pressupõe que o demandante não tenha tido posse até o seu ajuizamento.

Normalmente, se busca o ingresso na posse fundado em um título de propriedade ${ }^{60}$. Logo, nesse caso, será uma ação petitória, porque a causa de pedir é a propriedade, mas o seu pedido é possessório.

Contudo, nada impede que se valha do instituto para assegurar o ingresso na posse ao possuidor legítimo já reconhecido também, em face do proprietário do bem.

É comum o pedido de imissão na posse na execução de sentença de ação reivindicatória de propriedade, mas é possível também como ação autônoma, como se está a ver, e é comum a sua verificação em arremates de leilão, por exemplo, porque uma vez arrematado o bem, se buscará a imissão na posse sem que para isso haja necessidade de mover uma ação reivindicatória de propriedade.

\subsection{A função do Ministério Público no âmbito cível}

\subsubsection{Ministério Público previsão geral}

Ab initio, importante colocar que o Ministério Público está regulado no capítulo IV, seção I, da CRFB/1988, entre os arts. 127 e 130-A.

Assim dispõe o art. 130, CRFB/1988 que estabelece as suas funções:

Art. 127. O Ministério Público é instituição permanente, essencial à função jurisdicional do Estado, incumbindo-lhe a defesa da ordem jurídica, do regime democrático e dos interesses sociais e individuais indisponíveis.

Portanto, da leitura do supracitado artigo, depreende-se que é atribuição precípua do Ministério Público defender a ordem jurídica, o regime democrático, os interesses sociais e individuais homogêneos.

${ }^{60}$ TARTUCE, Flávio. Op. cit., p. 63. 
Com efeito, compulsando o Novo Código de Processo Civil, verifica-se também um título destinado à Instituição (Título V), possuindo regramento entre os arts. 176 à 181.

De início, constata-se que o art. 176, CPC/2015 reproduziu o dispositivo constitucional no tocante as funções exercidas pelo Parquet, e coube ao art. 178, CPC/2015 estabelecer as hipóteses em que o órgão intervirá como fiscal da lei que são: (i) processos que envolvam interesse público ou social, (ii) processos que envolvam interesse de incapaz, (iii) processos que envolvam conflitos coletivos pela posse de terra urbana ou rural.

Assim, independentemente sobre o que verse o processo, se houver interesse público ou social envolvido, interesse de incapaz, seja este menor de idade, seja interditado, ou, por fim, conflitos coletivos sobre posse, haverá circunstância legitimadora da atuação do Ministério Público.

\subsubsection{Promotorias de Justiça Cíveis}

Mas por que analisar especificamente as promotorias cíveis? Isso se dá justamente pelo fato de serem delas a atribuição para funcionarem nas ações de usucapião e nas ações possessórias, quando necessário, e, também, por esse ser o tema sob análise da presente monografia.

Cabe mencionar, primeiramente, que as promotorias de justiça cíveis se subdividem por áreas, ou melhor dizendo, por órgãos de execução de atribuição específica.

E, tomando como referência o Ministério Público do Estado do Rio de Janeiro, a divisão internas dessas promotorias de justiça cíveis tem como órgãos de execução: (i) Promotorias junto às varas cíveis, (ii) Promotorias de Fazenda Pública, (iii) Promotorias de Fundações, (iv) Promotorias de Proteção 
aos Idosos e Portadores de Deficiência, (v) Promotorias de Registros Públicos, (vi) Promotorias de Registro Civil ${ }^{61}$.

Isto posto, dentre todas essas Promotorias de Justiça de âmbito cível, na atuação nos processos envolvendo posse e propriedade, a competência funcional interna é das Promotorias de Justiça cíveis junto às varas cíveis, possuindo, por conseguinte, outras atribuições específicas as demais Promotorias.

Dessa forma, o detido exame recairá, aqui, sobre esta última.

\subsubsection{Promotorias de Justiça Cíveis stricto sensu}

Essas Promotorias intervêm nas ações de seu interesse tanto junto às varas cíveis, quanto junto aos juizados especiais cíveis, à exceção das hipóteses de outras Promotorias de natureza cível de matéria especializada, isto é, elas não são necessariamente as únicas a atuarem nas varas ou juizados especiais cíveis ${ }^{62}$.

Ademais, bom pontuar que a competência dessas promotorias é residual, na medida em que se não for caso de intervenção de nenhuma das Promotorias cíveis específicas, caberá a Promotoria cível stricto sensu funcionar no processo.

Com efeito, esta Promotoria intervirá como custos legis nas ações que envolvam acidente de trabalho, em remédios e ações constitucionais (habeas data, habeas corpus, mandado de segurança, ação popular - a ação civil pública já é de competência da Promotoria de Tutela Coletiva ${ }^{63}$ ), interesse de incapaz, incluindo nestas as ações possessórias, já que a natureza dessas ações,

${ }^{61}$ (1) GOUVÊA, Marcos Antonio Maselli de Pinheiro et al. Manual de atuação funcional das Promotorias de Justiça Cíveis. p. 11-12.

62 (2) Ibid. p. 13.

${ }^{63}$ (3) Ibid. p. 38. 
per si, não justifica a intervenção ministerial, além da usucapião (pelo menos era assim até o antigo código de processo civil).

Portanto, se a ação versar sobre conflito possessório, a atuação, como fiscal da lei, do Parquet, não é automática, necessitando, para tanto, de uma outra causa acessória, ou melhor, principal, já que o conflito possessório é que será secundário.

Dentre essas causas pode haver interesse público ou social envolvido, pender interesse de incapaz, ou até mesmo ser um conflito de caráter coletivo pela posse.

Estando presentes uma dessas 3 (três) possibilidades, deverá o Ministério Público funcionar no devido feito.

Quanto a usucapião, deixar-se-á a análise da intervenção, com o advento do Novo Código de Processo Civil, para o próximo capítulo, antecipando somente que com o velho código processual, a previsão de atuação era expressa, não havendo, portanto discussão quanto a este ponto.

O interessante, por hora, de frisar é que mesmo em conflitos de natureza transindividual, como a usucapião coletiva, prevista na lei 10.257, a competência ministerial é da Promotoria cível stricto sensu ${ }^{64}$, visto que o instituto é instrumento hábil a regularização fundiária e a urbanização das áreas ocupadas, muitas das vezes destituídas de serviços básicos e essenciais, além é claro da falta de individualização das posses, dada a multiplicidade dos ocupantes em urbanização pobre e precária ${ }^{65}$.

\footnotetext{
${ }^{64}$ OLIMPIO, Daniel Lobo. Op. cit..

${ }^{65}$ GOUVÊA, Marcos Antonio Maselli de Pinheiro et al. Op. cit., p. 33.
} 


\section{Capítulo 3 - Atuação do Ministério Público no Código de Processo Civil de 1973}

\subsection{Regramento do $\mathrm{CPC} / 73$ e a expressa previsão de intervenção ministerial}

O Código de Processo Civil de 1973 em seu capítulo VII (Da Ação de usucapião de terras particulares), notadamente no art. 944 dizia que o Ministério Público deveria obrigatoriamente intervir em todos os atos do processo.

Verifica-se aqui a previsão de atuação compulsória, não sendo, por conseguinte, mera faculdade do órgão ministerial, ou, de igual modo, uma atuação calcada em uma daquelas causas gerais de intervenção, previstas no art. 81 no antigo código, quais sejam: (i) interesse de incapaz, (ii) nas causas concernentes ao estado da pessoa, pátrio poder, tutela, curatela, interdição, casamento, declaração de ausência e disposições de última vontade, (iii) litígios coletivos pela posse de terra rural, (iv) interesse público pela natureza da lide ou qualidade da parte.

Não, independentemente dessas circunstâncias autorizadoras de intervenção, o Parquet tinha que funcionar nas ações de usucapião por previsão expressa do legislador.

$\mathrm{Na}$ verdade, assim elegeu a processualística por entender a ação de usucapião como uma demanda de interesse público, então por isso a previsão, até mesmo para não restar dúvidas quanto a isso.

Importante ressaltar que o Ministério Público pode assumir a posição de parte ou de fiscal da lei em um processo, podendo em situações específicas atuar como substituto processual.

Nesse sentido, nas demandas de usucapião, funcionaria o Ministério Público na qualidade de custos legis, não agindo, então, como parte ou substituto processual e em alusão ao disposto no art. $83 \mathrm{c} / \mathrm{c}$ art. 944, CPC/1973, 
ele teria vista dos autos após as partes, sendo condição sine qua non a sua intimação de todos os atos praticados no processo, sob pena de nulidade processual $^{66}$.

Outrossim, uma vez constatada a ausência de intimação do MP, o processo deveria ser declarado nulo, desde o momento que a intimação que deveria ter acontecido não ocorreu, anulando todos os atos dali em diante praticados.

Por outro lado, se apesar de devidamente intimado, o órgão não promovesse as diligências necessárias que lhe incumbia, isso não implicava em nulidade, acarretando em responsabilidade disciplinar, se fosse o caso, interna corporis (até pela independência funcional verificada no art. 127, §1 $1^{\circ}$, CFRB/1988).

Como coloca José Carlos de Moraes Salles em sua obra, a intervenção do Parquet só se mostrava pertinente nas ações de usucapião, em razão do efeito ser erga omnes, ao passo que na alegação de usucapião em defesa, os efeitos da decisão seriam inter partes $^{67}$.

Outro ponto relevante é que não pode nas ações de usucapião, ou em qualquer outra, intervir o MP na qualidade de fiscal da lei e concomitantemente de curador especial (réu revel citado por edital), em decorrência do princípio da unidade e indivisibilidade do Parquet, o que impede, por oportuno, a atuação por dois órgãos de execução distintos. ${ }^{68}$

\subsection{Modalidades de intervenção do MP nas ações de usucapião}

À época da lei 5.869/1973, o Ministério Público, por conta do regramento posto pelo art. 944 deveria atuar em todas as modalidades de usucapião vistas no capítulo 2 que são: (i) usucapião extraordinária, (ii)

\footnotetext{
${ }^{66}$ (1) SALLES, José Carlos de Moraes. Op. cit., p. 246.

${ }^{67}$ (2) Ibid. p. 247.

${ }^{68}$ (3) Ibid. p. 248.
} 
usucapião ordinária, (iii) usucapião especial urbana, (iV) usucapião especial rural, (v) usucapião por abandono do lar e (vi) usucapião coletiva.

Então, a princípio a intervenção ministerial era ampla, englobando toda e qualquer hipótese de usucapião. Contudo, era entendimento consolidado que o MP atuaria somente nas ações de usucapião de bens imóveis, dispensando a intervenção nas ações de usucapião de bens móveis. Isso se deu pelo acolhimento do disposto no art. $1^{\circ}, \mathrm{V}$ da Deliberação $\mathrm{n}^{\circ}$ 20-A/2008 (ato normativo interno editado pelos Procuradores de Justiça). ${ }^{69}$

Assim, a regra era clara e direta, o funcionamento Parquet como fiscal da lei era amplo, desde que a ação fosse atinente a usucapião de bens imóveis.

Isso se dava em razão do interesse público que se vislumbrava nas ações de usucapião, na medida em que esse conflito teria o condão de repercutir na sociedade como um todo, já que a declaração de usucapião, instrumentalizada no registro do bem no Registro de Imóveis em nome do usucapiendo, caso a demanda fosse julgada procedente, geraria efeito erga omnes.

Como citado no sub-capítulo anterior, era entendimento jurisprudencial que a não intervenção do MP não era caso de nulidade em processos em que se alegasse usucapião como meio de defesa, em decorrência do efeito gerado da decisão.

De um lado ou de outro, é oportuno tecer algumas considerações.

Quanto ao interesse público subjacente às ações de usucapião, este seria no sentido de regularizar a propriedade em nome do novo proprietário que usucapiu o bem. Teria o MP interesse na regularização dessa situação registral do imóvel.

Em que pese esse argumento, a mera alteração registral do imóvel para que passe a constar o nome de uma pessoa ao invés de outra, possuindo o imóvel em questão devida certidão de ônus reais, com identificação de

${ }^{69}$ GOUVÊA, Marcos Antonio Maselli de Pinheiro et al. Op. cit., p. 30. 
matrícula, per si, não configura um interesse público, sendo tão somente um direito de interesse particular, portanto disponível.

Haveria que ter outra circunstância geradora de interesse público, seja a falta de registro do imóvel (interesse na regularização de um bem irregular), seja a natureza do bem, seja o interesse social a ele vinculado.

Em relação a alegação de usucapião em defesa, parece acertado a posicionamento de não intervenção do Ministério Público, porque, em última análise, os efeitos da decisão serão somente entre as partes mesmo, já que, para que gere efeitos para toda a coletividade, necessário se apresenta o manejo de ação própria, em que serão obedecidos os requisitos legais para tanto ainda não observados, como a citação dos confinantes, intimação das Fazendas (União Federal, Estado e Município), bem como a publicação de edital, em veículo de grande circulação pública, para ciência de terceiros eventuais interessados. Só cumprido esse procedimento a declaração de usucapião terá força, quanto aos seus efeitos erga omnes.

Isto posto, sob a égide do CPC/1973, o Ministério Público deveria atuar, sendo intimado de todos os atos do processo, em todas as ações de usucapião (demanda usucapienda) de bens imóveis (apesar de existir usucapião de bens móveis e de outros direitos reais usucapíveis como visto no capítulo 2) por determinação expressa do diploma processual civil brasileiro.

\subsection{Atuação do MP nas ações possessórias}

No tocante as ações possessórias, estipulava de modo diverso o velho código de processo civil, visto que, diferentemente da usucapião, não havia previsão expressa para atuação ministerial no processo, incidindo, portanto, à espécie, a regra geral.

A redação do art. 82, CPC/1973, in verbis:

Art. 82. Compete ao Ministério Público intervir:

I - nas causas em que há interesses de incapazes;

II - nas causas concernentes ao estado da pessoa, pátrio poder, tutela, curatela, interdição, casamento, declaração de ausência e disposições de última vontade; 
III - nas ações que envolvam litígios coletivos pela posse da terra rural e nas demais causas em que há interesse público evidenciado pela natureza da lide ou qualidade da parte.

Logo, nas ações possessórias, o funcionamento do MP no feito se legitimava quando verificada algumas das circunstâncias autorizadoras da intervenção, isto é, a presença de interesse público ou social, o litígio de posse de terra coletiva, o interesse de incapaz, ou se a causa versasse sobre estado da pessoa, pátrio poder, tutela, curatela, interdição, casamento, declaração de ausência e disposições de última vontade.

Ora, se o processo não cuidasse de litígio envolvendo a posse de terra coletiva, a atuação do Parquet como custos legis nas demandas possessórias se dava de igual modo a de todas as outras ações, como, por exemplo, acidente de trânsito, plano de saúde, nulidade de negócio jurídico, indenizatória stricto sensu, dentre outras, ou seja, se houvesse interesse de incapaz envolvido ou interesse público e social.

Não havendo interesse de incapaz, seja porque não existia menores na demanda, seja porque não existia pessoa sem gozo de suas faculdades mentais que a tornasse inapta a realização dos atos da vida civil. Não havendo, ainda, interesse público, seja porque as partes eram particulares, seja porque o direito envolvido era de natureza disponível. Não havendo, por fim, interesse social, pelo fato de afetar tão somente a esfera privada das partes, não funcionava, na qualidade de fiscal da lei, o Ministério Público nas demandas possessórias, ainda mais antes da promulgação da constituição de 1988, que inaugurou uma outra discussão objeto do próximo capítulo.

\subsection{Jurisprudência à luz do CPC/1973}

Sobre o tema esposado, sobretudo quanto a necessidade de intervenção do Ministério Público quando ainda vigia o Código de Processo Civil de 1973 em ações de usucapião, a jurisprudência dos tribunais era assente, conforme julgados abaixo ementados: 
Ação de Usucapião. Sentença extinguindo o processo sem resolução do mérito, com fulcro no art. 267, III do CPC, ao fundamento de abandono do feito pela parte autora. Apelo manejado pela parte autora, levantando a nulidade da sentença, por ausência de intimação pessoal. Intervenção obrigatória do Ministério Público, que não foi intimado quando devia sê-lo. Nulidade absoluta. Aplicação dos artigos 84, 246 e 944, ambos do CPC. Autora que não se manifestou, entretanto, não foi intimada pessoalmente para dar andamento ao feito, sob pena de extinção. Violação do devido processo legal. Precedentes. SENTENÇA ANULADA DE OFÍCIO, nos termos do art. 557 do CPC, determinando que o feito retorne à Vara de origem, para que os autos sejam remetidos ao Ministério Público, com vistas ao regular processamento. Prejudicada a apreciação do recurso interposto pela autora (TJ/RJ, Apelação n0030849-38.2010.8.19.0021, Décima Terceira Câmara Cível, Des. Rel. Sirley Abreu Biondi, julgado em 01 dez. 2014). (grifou-se).

Apelação. Ação de usucapião extraordinário. Sentença de extinção do feito sem análise do mérito. Nos termos do art. 246, do CPC, a ausência de intimação do Ministério Público para intervir no feito, conforme estabelecido no art. 944, do CPC, gera a nulidade dos atos processuais com o consequente prejuízo à parte autora. Dou provimento ao recurso, nos termos do art. 557, $\S 1^{\circ}$-A, do CPC (TJ/RJ, Apelação n ${ }^{\circ}$ 0073929-81.2012.8.19.0021, Terceira Câmara Cível, Des. Rel. Helda Lima Meireles, julgado em 21 out. 2014). (grifou-se).

Direito Civil e Processual Civil. Ação de usucapião. Sentença de extinção do processo fundada no indeferimento da petição inicial. Apelo da parte autora e do Ministério Público. Razões recursais fundadas na ausência de inércia e de intimação do "Parquet". Reforma que se impõe. Ausência de intimação do órgão ministerial, cuja intervenção, no caso, é obrigatória. Inteligência dos artigos 84, 246 e 944 do Código de Processo Civil. $O$ reconhecimento da nulidade do ato justifica-se não apenas por terem sido violadas as disposições do Código de Processo Civil acerca da obrigatoriedade da intervenção do órgão ministerial, mas também porque evidencia-se que houve prejuízo à parte autora. Processo que tramita há mais de 17 anos. Parte autora, usucapiente, que buscou atender, dentro da sua limitação econômica, todos os chamados e determinações do Juízo. Requerimento de prova oral que não foi sequer apreciado, mas que poderia, somado às demais provas, ensejar o julgamento do processo com resolução de mérito. Ausência de inércia. "Error in procedendo". Sentença que se cassa. Recursos providos de plano. CPC (TJ/RJ, Apelação no 0021376-45.1997.8.19.0001, Quarta 
Câmara Cível, Des. Rel. Marco Antonio Ibrahim, julgado em 07 out. 2014).(grifou-se).

APELAÇÕES CÍVEIS. USUCAPIÃO. SENTENÇA PROFERIDA SEM A PRÉVIA INTIMAÇÃO DO MINISTÉRIO PÚBLICO PARA MANIFESTAÇÃO. ERRO NO PROCESSAMENTO DA DEMANDA. NÃO OBSERVÂNCIA DO ARTIGO 944 DO CPC. RECURSOS DE APELAÇÃO PROVIDOS. SENTENÇA ANULADA. 1. O julgamento de demanda de usucapião sem a prévia intimação do Ministério Público caracteriza erro em seu processamento, por violar o comando do artigo 944 do código de processo civil1, que determina que o Parquet intervenha em todos os atos do processo de usucapião. 2. Diante do exposto, dou provimento aos recursos de apelação, nos termos do artigo 557, $\S 1^{\circ}$ - A do CPC, para anular a sentença e determinar o prosseguimento do processo, com a finalidade de que o Ministério Público atuante junto ao primeiro grau de jurisdição tenha a oportunidade de se manifestar no processo, antes do julgamento da causa pelo juiz de piso (TJ/RJ, Apelação $\mathrm{n}^{\circ}$ 0012242-37.2006.8.19.0014, Décima Segunda Câmara Cível, Des. Rel. CherubinHelcias Schwartz Júnior, julgado em 07 out. 2014). (grifou-se).

Apelação. Ação de Usucapião. Sentença de procedência. Ausência de intimação do Ministério Público e da União. Violação aos arts. 246 e 942 a 944 do CPC e ao princípio do devido processo legal. Nulidade absoluta. Anulação da sentença de ofício, para determinar o prosseguimento da demanda com a intimação da União e do Parquet para se manifestarem no feito. (TJ/RJ, Apelação $\mathrm{n}^{\circ}$ 000170350.2005.8.19.0045, Vigésima Segunda Câmara Cível, Des. Rel. Carlos Eduardo Moreira Da Silva, julgado em 02 out. 2014). (grifou-se).

APELAÇÃO CÍVEL. BENS IMÓVEIS. AÇÃO DE USUCAPIÃO. NULIDADES PROCESSUAIS. DESCONSTITUIÇÃO DA SENTENÇA QUE SE IMPÕE. Na ação de usucapião é obrigatória a intervenção do Ministério Público em todos os atos processuais, nos termos do art. 944 do CPC. No caso, restou demonstrada a ausência de intimação do representante ministerial. Evidenciadas, ainda, outras nulidades, deve ser desconstituída a sentença. DERAM PROVIMENTO À APELAÇÃO, DESCONSTITUINDO A SENTENÇA. UNÂNIME. (TJ/RS, Apelação Cível no 70056520778, Vigésima Câmara Cível, Des. Rel. Walda Maria Melo Pierro, julgado em 12. mar. 2014) (grifou-se). 
APELAÇÃO CÍVEL. USUCAPIÃO EXTRAORDINÁRIA. SENTENÇA DE PROCEDÊNCIA. RECURSO DOS RÉUS. AUSÊNCIA DE INTIMAÇÃO DO MP. CASO DE INTERVENÇÃO OBRIGATÓRIA. PARECER DO MP EM SEGUNDO GRAU. SENTENÇA DESCONSTITUÍDA. Tratando-se de feito que exige intervenção obrigatória do Ministério Público (ação de usucapião, art. 944 do CPC), a falta de intimação do MP implica nulidade do feito. SENTENÇA DESCONSTITUÍDA. (TJ/RS, Apelação Cível $\mathrm{n}^{\circ}$ 70056775117, Décima Nona Câmara Cível, Des. Rel. Mylene Maria Michel, julgado em 29 abr. 2014) (grifou-se).

APELAÇÃO CÍVEL. AÇÃO DE USUCAPIÃO EXTRAORDINÁRIA. AUSÊNCIA DE INTIMAÇÃO DO MINISTÉRIO PÚBLICO. INTERVENÇÃO OBRIGATÓRIA. EXEGESE DO ART. 944 DO CÓDIGO DE PROCESSO CIVIL. NULIDADE SUSCITADA PELO REPRESENTANTE DA PROCURADORIA-GERAL DE JUSTIÇA. SENTENÇA CASSADA EX OFFICIO. RECURSO PREJUDICADO.

Merece ser decretada a nulidade do processo de usucapião quando não realizada a intimação do Ministério Público para intervir no feito, já que obrigatória a sua participação.

"A não intervenção do Ministério Público em primeiro grau de jurisdição pode ser suprida pela intervenção da Procuradoria de Justiça perante o colegiado de segundo grau, em parecer cuidando do mérito da causa, sem que haja arguição de prejuízo ou alegação de nulidade. Contudo, manifestando-se o órgão do Ministério Público pela ocorrência de prejuízo diante da ausência de sua intervenção em primeiro grau, impõe-se a decretação da nulidade" (STJ, EDcl no REsp 1184752/PI, Rel. Ministro Luis Felipe Salomão, Quarta Turma, j. em 16-10-2014) (TJ/SC, Apelação Cível no 2014.063571-0, Terceira Câmara de Direito Civil, Des. Rel. Regina Aparecida Soares Ferreira, julgado em 18 nov. 2014) (grifou-se).

USUCAPIÃO. AUSÊNCIA DA OBRIGATÓRIA INTERVENÇÃO DO MINISTÉRIO PÚBLICO. AFRONTA AO COMANDO DO ART. 944 DO CPC. NULIDADE EVIDENCIADA NOS TERMOS DOS DISPOSITIVOS 84 E 246 DO CÂNONE PROCESSUAL. DECISUM CASSADO. RECURSO CONHECIDO E PROVIDO. "A norma do art. 249, $\S 1^{\circ}$, do CPC, que positiva o brocardo 'pas de nulitésansgrief', não impede a decretação da nulidade do processo desde a citação, por falta de intervenção do Ministério Público, porque tal disposição deve ser interpretada em conjunto com aquelas insertas nos arts. 84 e 246 do mesmo Código, que expressamente cominam de nulidade os atos praticados sem a intervenção do 
Ministério Público, nos processo em que sua participação era obrigatória, como é o caso dos autos". (Recurso Especial n. 586.956/PR, relator Teori Albino Zavascki, Primeira Turma do Superior Tribunal de Justiça, DJ de 01.02.2006). (TJ/SC, Apelação Cível $\mathrm{n}^{\circ}$ 2012.077089-8, de Braço do Norte, Sexta Câmara de Direito Civil, Des. Rel. Ronei Danielli, julgado em 07 mar. 2013). (grifou-se).

APELAÇÃO CÍVEL. AÇÃO DE USUCAPIÃO. FALTA DE INTIMAÇÃO DO MINISTÉRIO PÚBLICO. VIOLAÇÃO DO ARTIGO 12, § $1^{\circ}$, DA LEI $\mathbf{N}^{\circ} 10.257 / 01$ E, ARTIGOS 83, I E 246, AMBOS DO CPC. PRELIMINAR DE NULIDADE ABSOLUTA ACOLHIDA PARA ANULAR A SENTENÇA DE PRIMEIRO GRAU. UNANIMIDADE (TJ/PA, Apelação Cível de nº 2009.0273792991, Des. Rel. Marneide Trindade Pereira Merabet, julgado em 25 mai. 2009) (grifou-se).

Agora, quanto a intervenção nas ações possessórias, essas se dão apenas nas hipóteses previstas em leis e no art. 82, CPC/1973, não havendo previsão específica para tal intervenção, por si só, e também são uníssonos os julgados, conforme entendimento que se verá adiante.

Além de não haver previsão do antigo CPC quanto a intervenção do Parquet em ações possessórias, como havia em relação as ações de usucapião, se verificará que a simples condição de pessoa idosa na demanda não enseja o funcionamento da instituição como custos legis, porquanto tal condição não caracteriza a incapacidade, per si, circunstância legitimadora da atuação do MP.

Seguem, a seguir, alguns julgados dos tribunais brasileiros, acerca da não intervenção do Ministério Público nas ações possessórias quando não verificadas as causas autorizadoras do art. 82, CPC/1973:

APELAÇÃO CÍVEL. IMISSÃO NA POSSE. Preliminar de nulidade pela ausência de intervenção do Ministério Público que não prospera, eis que não se insere em uma das hipóteses do artigo 82 do CPC. Lapso temporal configurado considerando o que estabelece o parágrafo único, do artigo $1.238 \mathrm{c} / \mathrm{c}$ artigo 2.029, ambos do CC/2002. Posse mansa e pacífica demonstrada. Desnecessidade de se verificar o justo título e a boa-fé, eis que se trata de usucapião extraordinário. Sentença reformada, 
nos termos do artigo 557, $\S 1^{\circ}-\mathrm{A}$ do CPC, com a consequente inversão dos ônus sucumbenciais (TJ/RJ, Apelação cível $\mathrm{n}^{\circ}$ 012669868.2008.8.19.0001, Décima Segunda Câmara Cível, Rel. Des. Cherubin Helcias Schwartz Júnior, julgado em: 13 mar. 2014) (grifou-se).

AÇÃO DE REINTEGRAÇÃO DE POSSE INTENTADA POR ADQUIRENTES DE IMÓVEL DE PESSOA JURÍDICA. ALIENAÇÃO DO BEM POR UM DOS DOIS SÓCIOS-GERENTES. NÃO DESOCUPAÇÃO DO IMÓVEL NO PRAZO PACTUADO. AJUIZAMENTO DE AÇÃO DE OPOSIÇÃO, CAUTELAR INOMINADA E DECLARATÓRIA DE NULIDADE DE ATO JURÍDICO PELO SÓCIO-GERENTE QUE NÃO FIRMOU O CONTRATO DE COMPRA E VENDA. AFIRMAÇÃO DE QUE SERIAM NECESSÁRIAS AS ASSINATURAS DE AMBOS OS SÓCIOS-GERENTES PARA VALIDADE DO CONTRATO. RECONHECIMENTO DO VÍCIO EM PRIMEIRA INSTÂNCIA. IMPROCEDÊNCIA DO PEDIDO DE REINTEGRAÇÃO E PROCEDÊNCIA DOS PEDIDOS NAS AÇÕES INTENTADAS PELO SÓCIO-GERENTE QUE NÃO PARTICIPOU DA ALIENAÇÃO. APELAÇÃO CÍVEL. PRELIMINAR DE CERCEAMENTO DE DEFESA. INOCORRÊNCIA. DILAÇÃO PROCESSUAL DESNECESSÁRIA. POSSIBILIDADE DE JULGAMENTO ANTECIPADO DA LIDE. CORRETA APLICAÇÃO DO ART. 330, I, DO CÓDIGO DE PROCESSO CIVIL. PRETENSÃO DE ANULAÇÃO DO FEITO POR AUSÊNCIA DE INTERVENÇÃO DO MINISTÉRIO PÚBLICO. AFIRMAÇÃO DE QUE EXISTE PEDIDO DE CANCELAMENTO DE REGISTRO PÚBLICO. MERA DECORRÊNCIA DA NULIDADE DO NEGÓCIO JURÍDICO. DESNECESSIDADE DE INTERVENÇÃO MINISTERIAL. PRECEDENTES. MÉRITO. ALIENAÇÃO DE BEM PERTENCENTE À PESSOA JURÍDICA. SOCIEDADE DE RESPONSABILIDADE LIMITADA. CONTRATO DE COMPRA E VENDA ASSINADO POR SOMENTE UM DOS SÓCIOS-GERENTES. CONTRATO SOCIAL QUE DELEGA PODERES PARA REALIZAÇÃO DE ATOS EM NOME DA SOCIEDADE A AMBOS OS SÓCIOS-GERENTES. NECESSIDADE DE ASSINATURA DOS DOIS SÓCIOS-GERENTES. AUSÊNCIA DO CONSENTIMENTO VÁLIDO E EFICAZ DE UMA DAS PARTES. COMPRA E VENDA INEXISTENTE. PRECEDENTES. I - A manifestação volitiva da pessoa jurídica somente se tem por expressa quando produzida pelos seus "representantes" estatutariamente designados. II - No caso de ser o ato praticado pela pessoa jurídica representada por apenas um dos seus sócios, quando seus estatutos determinam seja ela representada pelos dois 
sócios em conjunto, o que ocorre não é deficiência na representação, no sentido técnico-jurídico, que aceita convalidação, mas ausência de consentimento da empresa, por falta de manifestação de vontade, requisito fático para a formação do ato. III - $\mathrm{O}$ ato jurídico para o qual não concorre o pressuposto da manifestação de vontade é de ser qualificado como inexistente, cujo reconhecimento independe de pronunciamento judicial, não havendo que invocar-se prescrição, muito menos a do art. 178 do Código Civil. (REsp 115966/SP, Min. Sálvio de Figueiredo Teixeira, Quarta Turma, julgado em 17/2/2000, publicado no DJ em 24/4/2000, p. 56) NÃO PROVIMENTO DO RECURSO. (TJ/SC, Apelação Cível no 1998.003813-8, de Blumenau, Des. Rel. Jorge Schaefer Martins, Segunda Câmara de Direito Civil, julgado em 10 nov. 2005). (grifou-se).

AGRAVO DE INSTRUMENTO. POSSE (BENS IMÓVEIS). EMBARGOS DE TERCEIRO. ESTATUTO DO IDOSO. AUSÊNCIA DE INTERVENÇÃO DO MINISTÉRIO PÚBLICO. NULIDADE. INOCORRÊNCIA. Nos termos da lei 10.741/03, a ausência de intervenção do Ministério Público acarreta nulidade do feito. No entanto, desnecessária a intervenção do órgão eis que a presente demanda não versa sobre os direitos protegidos pela referida lei. Igualmente, não se verifica a situação de risco do idoso, mencionada pelos arts. 43 e 77 III do referido diploma. Ausência de prejuízo aos recorrentes. Decisão mantida. Precedentes jurisprudenciais. Em decisão monocrática, nego seguimento ao agravo de instrumento. (TJ/RS, Agravo de Instrumento $\mathrm{n}^{\circ}$ 70061223566, Vigésima Câmara Cível, Des. Rel. Glênio José Wasserstein Hekman, Julgado em 27 out. 2014). (grifou-se).

APELAÇÃO CÍVEL. POSSE (BENS IMÓVEIS). AÇÃO DE REINTEGRAÇÃO DE POSSE. 1. ALEGAÇÃO DE NULIDADE POR AUSÊNCIA DE INTERVENÇÃO DO MINISTÉRIO PÚBLICO. NÃO RECONHECIMENTO. CASO EM QUE NÃO SE ESTÁ A TRATAR DE DIREITO COLETIVO E, SIM, DE LITISCONSÓRIO PASSIVO. AUSÊNCIA DAS HIPÓTESES DO ART. 82 DO CÓDIGO DE PROCESSO CIVIL. 2. CERCEAMENTO DE DEFESA INOCORRENTE. REVELIA. OS RÉUS FORAM CIENTIFICADOS DO PRAZO PARA CONTESTAR EM ATA DE AUDIÊNCIA, SILENCIANDO. MANTIDA A DECRETAÇÃO DE REVELIA. DESNECESSÁRIA A INTIMAÇÃO ACERCA DA PRODUÇÃO DE PROVAS. CASO DE JULGAMENTO ANTECIPADO. 3. MÉRITO. COMPROVADA A POSSE ANTERIOR DOS AUTORES E O ESBULHO PRATICADO PELOS RÉUS. SITUAÇÃO CONCRETA EM QUE SE RECONHECE QUE O 
PROBLEMA SOCIAL DA MORADIA NÃO PODE SER IMPUTADO AO PARTICULAR. MANUTENÇÃO DA SENTENÇA DE PROCEDÊNCIA. RECURSO DESPROVIDO. (TJ/RS, Apelação Cível no 70048092266, Décima Sétima Câmara Cível, Des. Rel. Luiz Renato Alves da Silva, julgado em 17 abr. 2014) (grifou-se).

DIREITO PROCESSUAL CIVIL - AGRAVO DE INSTRUMENTO REINTEGRAÇÃO DE POSSE - DECISÃO AGRAVADA QUE INDEFERIU O REQUERIMENTO DE INTERVENÇÃO MINISTERIAL - SIMPLES CONDIÇÃO DE PESSOA IDOSA QUE NÃO IMPÕE A INTERVENÇÃO MINISTERIAL - ATUAÇÃO DO PARQUET QUE DEVE SER REAL PESSOAL E IMINENTE PRECEDENTES - DECISÃO QUE SE MANTÉM. 1. Cuida-se de agravo de instrumento interposto contra decisão que, em demanda de reintegração de posse movida pela recorrida em face da recorrente, indeferiu o requerimento de intervenção ministerial formulado pela ora agravante, ao fundamento de que a simples condição de pessoa idosa não impõe a intervenção do Ministério Público.2. Alega a agravante que a decisão deve ser reformada, máxime porque, além da condição de idosa, a recorrente também se encontra em situação de risco.3. Manifestação da douta Procuradoria de Justiça pelo desprovimento do recurso, ao fundamento de que não restou demonstrada hipótese que ensejasse a intervenção do Parquet, notadamente porque o só fato de a parte ré ostentar a qualidade de pessoa idosa não impõe tal atuação, inexistindo elementos que corroborem a situação de risco alegada. 4. In casu, não se verifica a verossimilhança das alegações da agravante, na medida em que, o próprio Ministério Público, cuja intervenção é requerida nestes autos, se manifestou no sentido da desnecessidade de sua atuação.5. Na oportunidade, restou ainda consignado que a condição de risco da pessoa idosa, a determinar a intervenção ministerial, deve ser real, pessoal e iminente. Precedentes.NEGO SEGUIMENTO AO RECURSO, COM ESPEQUE NO ART. 557, CAPUT, DO CPC. (TJ/RJ, Agravo de Instrumento $\mathrm{n}^{\circ}$ 0046720-40.2011.8.19.0000, Quarta Câmara Cível, Rel. Des(a). Marcelo Lima Buhatem, julgado em 13 abr. 2012).

ACÓRDÃO "POSSESSÓRIA. REINTEGRAÇÃO DE POSSE. INTERVENÇAÕ DO MINISTÉRIO PÚBLICO. DESNECESSIDADE. PODER DE FATO SOBRE A COISA. ESBULHO CARACTERIZADO. DANO MORAL. CABIMENTO. OBSERVÂNCIA DOS PRINCÍPIOS DA RAZOABILIDADE E PROPORCIONALIDADE. RECURSO DESPROVIDO. 1- $O$ fato de a apelante ser pessoa de idade avançada, por si só, não autoriza a intervenção obrigatória do Ministério 
Público, sendo certo que a demanda originária tem natureza patrimonial disponível. 2- Da mesma forma, não merece prosperar a alegação de cerceamento de defesa, considerando que o anterior patrono dos réus foi devidamente constituído (fls. 48) e intimado de todos os atos processuais. 3- No mérito, convém salientar que um dos efeitos mais importantes da posse é a proteção interdital, que abrange o desforço possessório e os interditos propriamente ditos. 4- Esta proteção concedida pelo ordenamento jurídico independe da apresentação de qualquer título e decorre da simples situação fática existente, lembrando-se ainda que, a ela podem recorrer todos os possuidores diretos ou indiretos. 5- Do que consta dos autos, restou comprovado o esbulho, vez que os documentos e provas testemunhais produzidas não deixam dúvidas de que o apelado residia no imóvel e só se ausentou quando ficou internado. 6- Quantum indenizatório fiel ao princípio da razoabilidade. 7- Desprovimento do recurso." (TJ/RJ, Apelação Cível $\mathrm{n}^{\circ}$ 0019990-87.2012.8.19.0054, Vigésima Câmara Cível, Rel. Des(a). Leticia De Faria Sardas, julgado em 12 nov. 2014). 


\section{Capítulo 4 - Novo regramento trazido pelo Novo Código de Processo Civil}

\subsection{Regramento do CPC/15 e a nova interferência do Parquet}

O novo Código de Processo Civil, por mais que tenha inovado na ordem jurídica em relação ao CPC/1973, ao ponto de ter que sobrevir um novo diploma (as reformas não eram mais suficientes), manteve, no que o legislador entendeu devido, praticamente ipsis litteris, as boas regras que se adequavam a nova sistemática inaugurada.

Todavia, desse modo não procedeu quanto as ações de usucapião, vez que alterou, por completo, a positivação da matéria em relação ao CPC/1973.

Com efeito, deixou de existir o capítulo VII "Da ação de usucapião de terras particulares", não havendo correspondência no Novo Código, e mais, não se repetiu a expressa regra de que a intervenção do Ministério Público era obrigatória em ações dessa natureza.

Diante disso, emergiu um debate acerca da manutenção da necessidade de funcionamento do Parquet, como fiscal da lei, nas demandas de usucapião.

De um lado, o qual parece acertado, como adiante se verá, existe tese da ausência de intervenção em usucapião lato sensu, uma vez que foi opção do legislador em retirar essa previsão do código processual, equiparando-se, portanto, em última análise, as ações possessórias (não chega a se equiparar integralmente como se verá).

De outro, uma corrente, que se apresenta como minoritária, defende a tese da manutenção do interesse do MP em atuar nesses processos, por ser patente o interesse público nessas demandas.

Ora, o que se pode colocar é que se não há mais previsão expressa de atuação do Ministério Público nas ações de usucapião, então, toda e qualquer intervenção se justificará no art. 178, CPC/2015, ou em outra legislação que expressamente preveja o funcionamento da Instituição. 
Assim, o art. 178, CPC/2015 modernizando o antigo art. 81, CPC/1973 elencou que intervirá o MP como fiscal da lei nas seguintes hipóteses: (i) interesse público ou social, (ii) interesse de incapaz, (iii) litígios coletivos pela posse de terra rural ou urbana.

Ou seja, para aqueles que se filiam a corrente da permanência da intervenção, a causa legitimadora terá que estar em uma dessas hipóteses supracitadas, e, ao que parece, sobretudo no inciso I que dispõe acerca do interesse público e social.

Somente vendo dessa maneira é que é possível tutelar a intervenção ampla, em qualquer modalidade de usucapião, porque se assim não fosse, algumas das espécies de usucapião caducariam quanto ao interesse do Parquet.

Entendendo que a questão da usucapião é de interesse público, social, ou ambos combinados, fica claro que o Ministério Público deve preservar o seu funcionamento nessas demandas, como era realizado à luz da lei 5.869/1973.

Conquanto as boas razões acima ventiladas, esse não se mostra como o melhor entendimento pelas explicações a que se passa a expor.

Se o legislador optou por modificar a legislação no sentido de retirar a previsão de intervenção do Ministério Público nas ações de usucapião, ele o fez com um propósito específico, porque não há sentido de modernizar a legislação para retirar uma regra cristalina e colocar uma regra equivalente obscura, de caráter subjetivo, que suscite interpretação.

Então, de início, essa não pode ter sido a finalidade almejada pelo legislador, muito pelo contrário, ele buscou e modificou, de fato, o funcionamento do Ministério Público nas demandas de usucapião.

Além disso, analisando detidamente todas as hipóteses de usucapião, nem todas possuem um interesse público ou social subjacente, porquanto, muitas das vezes, envolvem interesses patrimoniais particulares, em nada repercutindo na esfera social ou pública. 
A usucapião, à título de exemplo, de uma ampla casa situada na zona sul carioca ou paulista pertencente a uma pessoa física maior e capaz não tem nenhum interesse público ou social envolvido, a princípio, havendo, tão somente, interesse de origem privada e patrimonial.

Portanto, seja pela falta de previsão expressa, seja pela inexistência de interesse público ou social intrínseco, não deve o Ministério Público intervir em toda e qualquer modalidade de usucapião.

Isso é claro quanto a usucapião de bens imóveis, porque quanto a bens móveis, como já visto, é pacífico o entendimento que não há causa que justifique a atuação ministerial.

Enfim, por mais que ainda não seja unânime, afigura-se como nova a intervenção do MP nas ações de usucapião, um tanto por opção política, um pouco por conteúdo envolvido nas ações de usucapião, de modo que com o advento do NCPC, passa a intervir o Parquet, nos seguintes cenários: (i) usucapião que haja interesse público, (ii) usucapião que haja interesse social, (iii) usucapião que haja conflito sobre posse coletiva, (iv) usucapião que haja interesse de incapaz, (v) usucapião que haja expressa previsão de intervenção constitucional ou em legislação extravagante.

Adiante, no sub-capítulo "Omissão legal do NCPC quanto a atuação do MP nas ações de usucapião" se colocará, fundamentadamente, em quais espécies de usucapião a intervenção permanece como legítima e em quais não se faz mais necessária.

\subsection{Interpretação civil-constitucional do Art.178, CPC, nas ações possessórias}

Quanto a intervenção do Ministério Público, como custos legis, nas ações possessórias, tal entendimento não se alterou em relação ao estabelecido pelo CPC anterior.

Ocorre, apenas, que agora a intervenção se fundamenta no teor do art. 178, CPC/2015, isto é, se legitima nas hipóteses de interesse de incapaz, de 
interesse público ou social e nos litígios coletivos atinentes a terras urbanas ou rurais.

Basicamente, o art. 178, CPC/2015 repetiu a regra do art. 82 do velho diploma, de maneira, que praticamente nada mudou, intervindo o Parquet quando verificadas essas circunstâncias gerais autorizadoras, que as são para qualquer tipo de ação e não só para as ações possessórias.

Mas, apesar disso já ter sido tratado em linhas anteriores, um ponto de latente discussão e debate construtivo e enriquecedor diz respeito ao interesse de incapaz.

Ora, inexiste controvérsia que havendo interesse de incapaz, o Ministério Público deve funcionar no feito como fiscal da lei. Quanto a isso não há dúvida. No entanto, o que vem a ser essa cláusula geral "interesse de incapaz" que chama a atuação do MP? Até que ponto o interesse de incapaz justifica a intervenção do membro do Ministério Público, sobretudo em ações possessórias? Esse tema rende bons entreveros e merece algumas considerações.

Com a promulgação da constituição de 1988, inaugurou-se um novo cenário constitucional, onde se criaram diversos direitos e garantias individuais e sociais.

Dentre esses se verifica a função social da propriedade (art. $5^{\circ}$, XXXIII, CRFB/1988), os direitos à alimentação, ao trabalho e à moradia (art. $6^{\circ}$, CRFB/1988), o fundamento da dignidade da pessoa humana (art. $1^{\circ}$, III, CRFB/1988).

Aliado a isso, se verifica também a modernização do instituto da posse, autônomo e independente da propriedade, como visto no capítulo I, em que a posse vem a tutelar não só situações jurídicas patrimoniais, mas também existenciais, isto é, a posse tem o condão de promover esses atributos humanos como a dignidade da pessoa humana e os direitos básicos de habitar, trabalhar e alimentar. 
Por fim, ainda existe o capítulo constitucional III "da política agrícola e fundiária e da reforma agrária" para salvaguardar os interesses sociais inerentes a posse, prevendo meios de torná-la produtiva, útil e justa.

Cotejando tudo isso, a fim de proteger e resguardar esses interesses elencados, poder-se-ia o Ministério Público atuar no processo para preservar, em última instância, esses direitos atinentes aos incapazes.

Em vista da preservação de um direito de moradia, de um direito à alimentação (posse rural sobretudo), da função social da posse, da dignidade da pessoa humana de incapaz, seria legítima a intervenção do Ministério Público ainda que este não fosse parte na relação processual, tendo, por conseguinte, apenas interesse reflexo.

Impossível valorar negativamente um membro do Parquet que atue nessas condições, a um, porque existe o princípio da independência funcional elencado no art. $127, \S 1^{\circ}$, in fine, $\mathrm{CRFB} / 1998$, a dois porque ele estará atuando em atendimento de interesse de incapaz, nos moldes do art. 178, II, CPC/2015.

Verbi gratia, seria capaz de alguns membros atuarem em ações de reintegração de posse, cumulada com pedido de imissão na posse, em que no polo passivo figurasse uma mãe com filhos menores, ou, que cuidasse de um pai incapaz civilmente falando. Com o intuito de proteger os interesses desses vulneráveis, interviria o MP em nome do interesse de incapaz, mesmo que reflexo.

Em crítica, essa atuação é casuística e dependerá do quão fundamental pondere e valore o membro do Ministério Público, mesmo que o interesse de incapaz seja indireto.

Em que pese os bons fundamentos de escopo social e constitucional e respeitando o princípio da independência funcional, por mais cruel que possa soar em certos casos, não deve o Ministério Público intervir em ações possessórias, ou em qualquer outro processo, que haja interesse de incapaz 
reflexo, de modo que o incapaz deve integralizar a relação processual para justificar a intervenção ministerial.

Isso porque, tem que se ter em conta qual a verdadeira função do Ministério Público, que não é tutelar, como se auxiliar fosse, do patrono da parte incapaz. Não é essa a atribuição do MP nesses tipos de demanda.

Por outro lado, o Parquet funcionará nessas demandas como fiscal da lei, a saber: (i) ver se está ocorrendo alguma violação a interesse de incapaz por este estar nessa condição (ii) ver se o devido processo legal está sendo cumprido.

Outrossim, em nome do devido processo legal (art. 5', LIV, CRFB/1988) e da segurança jurídica (art. 5º XXXVI), o Ministério Público deverá, tecnicamente, se limitar a verificar o bom andamento processual, nessas ações que legitimam a sua atuação.

Tanto é assim, que pode o Ministério Público oficiar em discordância da pretensão do incapaz, não sendo obrigatória defender a sua tese, seja como autor, seja como réu, uma vez que sua atribuição é tão somente como custos legis.

Dessa forma, alargar a intervenção a pessoas que não são partes no processo é desvirtuar a competência funcional da Instituição, é querer resolver intróitos para além do processo.

Isso, por consequência, geraria alguns outros problemas, como subjetividade de intervenção, insegurança jurídica, atuações sem limites, já que o interesse de incapaz poderia ser procurado em qualquer questão anexa.

Assim, em observância a técnica atuação do Ministério Público, com as devidas ressalvas respeitosas que se fez, melhor entendimento não prospera, senão a intervenção ministerial nas causas em que incapaz esteja em um dos pólos da demanda. No caso, na ação possessória, por ser sobre esta o exame, porque não figurando como parte no processo, seu interesse será meramente indireto, reflexo e extraprocessual, impossibilitando a intervenção do Parquet. 
Esse é, inclusive, o entendimento exarado pelo Superior Tribunal de Justiça sobre o tema, o qual merece respeito e elogios.

\subsection{Omissão Legal do NCPC quanto a atuação do MP nas ações de usucapião}

Neste tocante, já foi colocado que a lei 13.105 retirou o capítulo VII "Da ação de usucapião de terras particulares" que vinha no CPC/1973, deixando, tão somente, como previsão de intervenção ministerial a regra geral preconizada no art. 178, CPC/2015.

No sub-capítulo supra 4.1 se analisou essa nova previsão legal e em que isso modificou a legitimidade de atuação do Parquet.

Agora, o objetivo é examinar em que espécies de usucapião, das vistas no capítulo II da presente monografia, o Ministério Público deve continuar intervindo e em quais não mais, em razão dessa omissão legal de funcionamento obrigatório nas ações de usucapião.

Isto posto, considerando o disposto nas legislações e a regra geral do art. 178, CPC/20015, deverá o MP funcionar nas seguintes espécies de usucapião: (i) usucapião especial urbana, (ii) usucapião especial rural, (iii) usucapião coletiva e, logicamente, não funcionará mais nas ações: (i) usucapião extraordinária, (ii) usucapião ordinária, (iii) usucapião por abandono do lar, pelos fundamentos que serão esposados em sequência.

Antes de mais nada, poderá vir a intervir o MP em ações de usucapião extraordinária, ordinária ou por abandono do lar, desde que elas possuam interesse público, social, ou interesse de incapaz envolvido, isto é, elas, por si só, não autorizam mais a atuação ministerial, como obrigatoriamente regrava o CPC/1973, mas presentes as cláusulas gerais de intervenção, funcionará o Parquet como custos legis como em qualquer outra ação.

Adentrando as espécies em específico, na usucapião especial urbana subsistiu a causa de intervenção do Ministério Público. Isso se dá em razão do forte caráter social dessa modalidade, uma vez que o usucapiente não pode ter 
outro imóvel em seu nome, seja urbano, seja rural, além é claro de ter que utilizá-lo para fins de moradia. É pré-requisito, portanto, da usucapião especial urbana o caráter social, de modo que é impossível se valer dessa espécie sem a finalidade social para fins de moradia. Ademais, para que não reste dúvidas quanto ao interesse social legitimador da intervenção, o Estatuto da cidade (lei $10.257 / 2001$ ), em seu art. $12, \S 1^{\circ}$, põe fim a discussão ao estabelecer:

Art. $12, \S 11^{\circ} \mathrm{Na}$ ação de usucapião especial urbana é obrigatória a intervenção do Ministério Público.

Logo, de acordo com o art. 178, I, in fine, CPC/2015 c/c art. 12, §1 ${ }^{\circ}$, da lei 10.257/2001, deverá atuar no feito o Parquet na usucapião especial urbana, a um por ser evidente o interesse social intrínseco à modalidade, a dois, por haver previsão expressa quanto a obrigatoriedade da intervenção.

Nesse passo, haverá também a preservação do funcionamento em ações de usucapião especial rural, por ser a ela inerente o caráter social da posse, em toda e qualquer hipótese, senão seria obstaculizado o manejo dessa espécie. O art. 1.239, CC/2002 coloca que nessa usucapião há exigência do demandante não ter outro imóvel, de tornar a área produtiva, bem como a ter como moradia, cumulativamente, portanto indiscutível o caráter social da posse ad usucapionem na hipótese. Desse modo, conserva-se a circunstância de atuação do MP, nos moldes do art. 178, I, in fine, CPC/2015.

Quanto a usucapião coletiva, preserva-se, também, a intervenção dada o forte caráter social subjacente as ocupações, normalmente realizadas por pessoas hipossuficientes, bem como a expressa previsão de funcionamento em litígios de posse coletivos, sendo imóvel rural ou imóvel urbano. Assim, tendo em vista o interesse social aparente e a expressa previsão do Código de Processo Civil atual, deverá o Parquet funcionar nessa espécie de usucapião, nos termos do art. 178, I e III, CPC/2015.

Vistas todas as espécies, as que, per si, legitimam a atuação ministerial e as que necessitam de circunstâncias gerais legitimadoras, por não possuírem 
motivos íntimos necessários, ou melhor, não terem o interesse social ou público vinculado de modo obrigatório a espécie, podendo este estar presente ou não, importante, ainda, ressaltar uma última hipótese de intervenção, que não diz respeito a uma modalidade específica.

Independentemente da ação proposta, haverá interesse público notório a ensejar a participação do Ministério Público, no processo, a falta de registro do imóvel usucapiendo, na medida que a Instituição deve oficiar no sentido da regularização deste, para que não subsistam imóveis irregulares.

Da análise conjunta do art. 167, I, 28, e do art. 176, caput, $\S 1^{\circ}$, I da lei de Registro Públicos (lei 6.015/1973), verifica-se a sentença declaratória de usucapião precisa do registro no Registro de Imóveis, devendo, ainda, ter cada imóvel matrícula própria. ${ }^{70}$

Neste ponto, existindo dúvida quanto ao procedimento de registro poderá intervir o MP, que pode, inclusive, interpor apelação caso não haja a adequada instrução, a fim de que se faça o devido registro, regularizando, assim, o imóvel (arts. 200 e 202, lei 6.015/1973).

Portanto, cotejando esses artigos, constata-se o interesse público do Parquet no procedimento de registro, podendo intervir para o seu adequado andamento por previsão expressa da lei 6.015/1973, assentando o interesse ministerial nas ações de usucapião em que o imóvel usucapiendo não possua registro.

Enfim, em resumo, dadas as razões acima, deverá funcionar o Ministério Público, como fiscal da lei, nas ações de usucapião, no CPC/2015, por:

a) inerente interesse social: (i) usucapião especial rural, (ii) usucapião coletivo. b)inerente interesse público: (i) ação de usucapião em que o imóvel usucapiendo não possua registro no Registro de Imóveis (irregularidade). 
c) previsão legal: (i) usucapião especial urbana.

d) quando presentes as cláusulas gerais: demais hipóteses, como em qualquer outra ação.

\subsection{Posições dos Promotores de Justiça Cíveis}

A fim de dar robusteza ao presente trabalho e ao entendimento apresentado, perguntas acerca do tema foram endereçadas aos Promotores de Justiça titulares das Promotorias de Justiças Cíveis da Comarca da Capital, na medida em que estes lidam com a problemática na prática forense.

Desse modo, foram feitos 3 indagações e assim se posicionaram os ilustres membros do Parquet:

1) A atribuição do Ministério Público nas ações de usucapião se alterou, com o advento do Código de Processo Civil de 2015? Se sim, em que casos deve continuar intervindo? Se não, a manutenção da atuação se dá sob que fundamento?

Dra. Maria da Glória Guarino de Oliveira Lucas, promotora titular da $1^{\text {a }}$ Promotoria de Justiça Cível:

"O atual CPC não faz menção à intervenção do Ministério Público nas ações de usucapião. As ações de usucapião de imóvel regularmente registrado refletem interesse meramente individual e disponível. Dessa forma, somente se justifica a intervenção na hipótese de o imóvel não ser registrado, em razão do interesse público na regularização da propriedade."

Dra. Flavia Figueiredo Roxo, promotora titular da $3^{\mathrm{a}}$ Promotoria de Justiça Cível:

"A meu ver, a Lei $n^{\circ}$ 13.105/2015 (Novo Código de Processo Civil) revogou totalmente os arts. 941 a 945 (correspondentes ao procedimento de usucapião de terras particulares). Isso implica dizer que não existe mais qualquer previsão na lei processual civil de obrigatoriedade de intervenção do Ministério Público nas ações de aquisição originária de bens imóveis.

Por essa simples razão, não há mais fundamento para intervenção. Para além disso, de fato, a maioria dos procedimentos envolvem interesses particulares da parte que pretende usucapir e, no máximo, entre o proprietário que consta no registro imobiliário e seus confinantes. Não há, verdadeiramente, na maioria das vezes, interesse público ou social, que

70 SIGNORINI, Terezinha de Jesus Souza et. al. Consulta n ${ }^{\circ}$ 66/2014 - CAOP Cível. <http://www.civel.mppr.mp.br/arquivos/File/consulta_66_sao_joao_triunfo_usucapiao_imovel_rural_s em_registro_atribuicao_mp_repercussoes_registro_publico.pdf>. Acesso em 11 mai. 2018 
poderia haver em caso de usucapião de terras públicas, mas tal previsão é vedada pelo art. 183, §3, da CF/88 e art. 102 do Código Civil. Prosseguindo, embora não haja mais previsão específica ante a revogação do procedimento especial da usucapião, as Fazendas serão sempre ouvidas nos casos em que tiver interesse (art. 722 do NCPC), razão pela qual permanecerão sendo notificadas para se manifestar nos autos, e eventual interferência em imóvel público ou foreiro será objeto de contestação pelos competentes membros das Procuradorias da União, dos Estados ou dos Municípios.

Portanto, nas ações cujo objeto versar sobre usucapião extraordinária (art. 1.238 do CC), usucapião conjugal (art. 1.240-A do CC) ou usucapião ordinária (art. 1.242 do CC), por si só, não mais deve haver obrigatoriedade de manifestação do órgão ministerial.

As exceções devem se restringir aos casos de ações que encerrem pedido com base (i) na usucapião especial urbana (art. 183, caput, da CF/88, c/c art. 1.240 do CC e art. $9^{\circ}$, da Lei $\mathrm{n}^{\circ}$ 10.257/2001 - Estatuto da Cidade), seja ela individual ou coletiva, em virtude da manutenção da obrigatoriedade de intervenção do Ministério Público (art. 12, §1 ${ }^{\circ}$, da Lei ${ }^{\circ}$ 10.257/2001); (ii) na usucapião de imóvel sem registro no ofício de imóveis, conforme se obtém da interpretação sistemática dos arts. 200 e 202, da Lei $n^{\circ} 6.015 / 73$, que indicam a atuação ministerial no procedimento de registro de imóveis, em caso de procedimento oficioso de dúvida, dado o notório interesse público; (iii) na usucapião individual de imóvel objeto de ocupações de caráter social, a atrair a atuação do Parquet pela presença do interesse social e (iv) na existência de interesse de parte incapaz.

Por esses fundamentos, sempre visando à satisfação plena do munus constitucional do Ministério Público, concentrando o foco da atuação nas causas em que verdadeiramente estejam presentes o interesse público, social, das minorias e dos incapazes, nesse sentido deve ser reconduzida a atuação do Parquet, de maneira a alcançar o seu verdadeiro lugar na defesa da ordem jurídica democrática e pluralista, atuando na defesa do interesse de todos (público ou social) e daqueles que, realmente, necessitam do amparo do órgão ministerial."

\section{Dra. Jacqueline Esther Abecassis, promotora titular da $4^{\text {a }}$ Promotoria de}

\section{Justiça Cível:}

"Entendo que a retirada a intervenção ministerial nas ações de usucapião foi um dos avanços trazidos com o novo C.P.C. Não há interesse público ou social na maioria das ações de usucapião, existindo apenas a discussão de interesses privados que fogem totalmente da função a ser desempenhada pelo Ministério Público. Evidente que havendo interesse coletivo ou quando efetivamente configurada função social da propriedade faz-se necessária à intervenção ministerial, vez que a discussão tem fundamento em hipóteses claras de atuação do Parquet."

\section{Dra. Mônica Soares Santos Corrêa, promotora titular da $5^{\text {a }}$ Promotoria}

\section{de Justiça Cível:}

"Sim, porque houve a revogação dos artigos 941 e 942, implicando na retirada da imposição legal de intervenção do MP nas ações de usucapião ordinárias e extraordinárias.

Hoje, embora a discussão já esteja praticamente encerrada a nível doutrinário processual, o certo é que, "interna corporis", ainda há quem defenda atribuição com base no interesse público/social.

Todavia, as promotorias de justiça cível da capital têm entendimento assente no sentido de que não havendo um incapaz no pólo ativo (já que no passivo nunca poderia ser o caso - as prescrições tem seu prazo obstado em face do incapaz), a hipótese está configurada como de interesse particular e meramente patrimonial." 
2) Caso não haja mais circunstâncias que justifique a intervenção ministerial, por que, de um modo geral, se verifica, ainda em 2018, o funcionamento do Parquet como custos legis nas ações de usucapião?

Dra. Maria da Glória Guarino de Oliveira Lucas, promotora titular da $1^{\mathrm{a}}$ Promotoria de Justiça Cível:

"A intervenção como custos legis ainda ocorre por falta de uma diretriz da Instituição a esse respeito. Como não há ainda entendimento consolidado nesse sentido, persiste a intervenção."

Dra. Flavia Figueiredo Roxo, promotora titular da $3^{\mathrm{a}}$ Promotoria de Justiça Cível:

"Provavelmente porque a par do advento do novo CPC, ainda há algumas hipóteses em que a atuação do Parquet se faz necessária em demandas de usucapião, conforme o entendimento esposado no item 1) do presente questionário".

Dra. Jacqueline Esther Abecassis, promotora titular da $4^{a}$ Promotoria de Justiça Cível:

"Infelizmente ainda prepondera em nossa instituição a ideia de que o Ministério Público não pode "abrir mão" de qualquer espaço alcançado e que "quanto mais intervenção melhor". Ocorre que tal posicionamento acaba por gerar um efeito contrário ao pretendido, vez que estando o Ministério Público em vários lugares não foca e não consegue ter uma atuação mais direcionada nas demandas que realmente urgem pela atuação ministerial."

Dra. Mônica Soares Santos Corrêa, promotora titular da $5^{\text {a }}$ Promotoria de Justiça Cível:

"Ao meu ver, mero conservadorismo e uma certa onipotência no sentido de considerar que o Juízo não fiscaliza a juntada criteriosa de documentos, cabendo a função ao MP em face de um suposto interesse público".

3) Nas ações possessórias, até que ponto o interesse de incapaz legitima a intervenção do Ministério Público? O interesse jurídico do incapaz, no processo, pode ser indireto ou reflexo? Ou o incapaz tem que integrar a relação processual, seja como autor, seja como réu?

Dra. Maria da Glória Guarino de Oliveira Lucas, promotora titular da $1^{\text {a }}$ Promotoria de Justiça Cível:

"Havendo interesse de incapaz, necessária a intervenção do Ministério Público. A questão do interesse reflexo deve ser avaliada caso a caso, uma vez que pode acabar por 
implicar em prejuízo ao próprio interesse de incapaz. Somente na avaliação do caso concreto é que se pode justificar a necessidade de integração da relação processual."

\section{Dra. Flavia Figueiredo Roxo, promotora titular da $3^{\mathrm{a}}$ Promotoria de}

\section{Justiça Cível:}

"Sem maiores digressões quanto ao espectro de abrangência da expressão "interesse de incapaz", prevista no art. 178, inciso II, do CPC, preme-se por consignar que, em ações possessórias, o fato de a parte residir no imóvel na companhia do incapaz não torna, por si só, obrigatória a intervenção do Parquet.

Isso porque a finalidade por detrás da intervenção ministerial diante da presença de incapazes é para que tal órgão labore em favor da correta e integral observância dos direitos daqueles que não podem agir sozinhos em juízo.

Sendo assim, o Ministério Público exerce o múnus, nessas situações, de alinhavar o potencial desequilíbrio da relação jurídica, minorando o comprometimento possivelmente resultante disso em relação ao contraditório, no que se refere à parte que ostenta incapacidade de fato e de direito. Em outras palavras, cabe ao Parquet aferir se os interesses dos incapazes estão sendo assegurados e respeitados a contento, seja do ponto de vista processual ou material.

Referida atribuição conferida a este órgão decorre de sua função institucional de defesa da ordem jurídica e, ainda, dos interesses individuais indisponíveis (arts. 127, caput, da CRFB), não sendo equivocado inserir dentro de tal categoria o respeito ao direito fundamental correspondente ao devido processo legal, em suas vertentes formal e material, assim como o contraditório e a ampla defesa.

Assim, quando a ação possessória é ajuizada somente contra a parte capaz, de sorte que não se está a manejar qualquer pretensão em desfavor do incapaz, não havendo, portanto, liame processual ou material entre este último e a parte contrária, reputamos descaracterizada a necessidade de intervenção do Ministério Público, à luz da ausência das premissas que a justificam e que foram acima aludidas.

Portanto, a simples possibilidade de o incapaz vir a ser atingido pelas consequências fáticas oriundas das ações possessórias não justifica a intervenção do Parquet como custos iuris, porquanto nessa situação se afigura a existência de interesse meramente reflexo de incapaz, e, por conseguinte, sem o anunciado lastro teleológico à atuação do órgão ministerial.

Caso se entendesse em sentido contrário, poder-se-ia chegar ao raciocínio extremo de que o Ministério Público teria o dever de intervir em toda e qualquer ação judicial relacionada a imóveis em que residam crianças, adolescentes ou portadores de deficiência mental, o que seria um manifesto desvirtuamento da sua missão constitucional."

\section{Dra. Jacqueline Esther Abecassis, promotora titular da $4^{\mathrm{a}}$ Promotoria de}

\section{Justiça Cível:}

"Seguindo o posicionamento já exposto nas questões acima, a atuação ministerial deve se pautar pelos interesses que deve velar. Entendo que o interesse de incapaz deve ser perquirido quando há possibilidade de efetivo dano ou prejuízo a ele na demanda. Não há necessidade do incapaz integrar a relação processual, muitas vezes o fato de não integrar é que deve dar ensejo a atuação ministerial, visto que não se encontra representado por qualquer das partes e há interesse do mesmo a ser preservado." 
Dra. Mônica Soares Santos Corrêa, promotora titular da $5^{\text {a }}$ Promotoria de Justiça Cível:

"O art. 178 do CPC é claro ao dispor que a existência do incapaz, ou melhor, do interesse de incapaz configura a atribuição do Parquet.

Todavia, o interesse há de ser direto, do mesmo, enquanto parte no processo."

\subsection{Lentidão da mudança prática de paradigma}

Neste ponto, a intenção é entender o porquê de o Ministério Público conservar, praticamente de forma integral, a sua atuação como acontecia à luz do CPC/1973, apesar da mudança de atribuição do MP trazida pelo Novo CPC vista e fundamentada ao longo deste trabalho.

Essa não é uma resposta muito fácil, mas observando o seu atuar prático, bem como as respostas que deram as ilustres promotoras no subcapítulo anterior, pode se chegar a algumas conclusões.

Em primeiro lugar, calcado na independência funcional, uma parte minoritária da Instituição, em que pese o posicionamento exarado, ainda defende que é indiferente a previsão de intervenção obrigatória em ações de usucapião, na medida em que todo e qualquer processo de usucapião envolve interesse público ou social, quando não interesse de incapaz, ou controvérsia pendente sobre terra coletiva. Assim, para essa corrente, o art. 178, CPC/2015 é bastante e autoriza o funcionamento do Parquet de maneira ampliada, como já era antes, em demandas dessa natureza.

Ainda assim, se verifica também que boa parte dos membros que se posicionam pela alteração da intervenção ministerial, ainda atuam, como se a lei não tivesse sido alterada e isso pode ser explicado de algumas formas.

Primeiro, essa manutenção se explica pela consonância com o posicionamento do magistrado que, por entender ser devida a atuação do MP, abre-se lhe vista, para falar nos autos. Uma vez aberta vista, ad cautelam, tem se verificado a intervenção do Ministério Público, ao invés de oficiar pela não atuação em certos casos. 
Outro fator preponderante é o cuidado que alguns membros têm em salvaguardar o princípio da indivisibilidade do Parquet, porque como ainda não há um posicionamento uníssono sobre o tema dentro mesmo da própria Instituição, para que alguns membros atuem e outros não, em que pese a independência funcional (princípio institucional do Ministério Público), ainda se espera pela unificação do entendimento, a fim de que se delimite a esfera de atuação, no sentido de dizer em quais espécies e por quais fundamentos devese funcionar nas ações de usucapião, porque quantos as ações possessórias, não há muita discussão, como já tratado.

Dessa forma, o que se vê, na prática, é um aguardo pelo Ministério Público de $1^{\circ}$ grau, sobretudo pelos promotores de justiça que defendem a alteração da atribuição do MP - que ressalta-se, novamente, são majoritários acerca do posicionamento de seu órgão de cúpula que, ainda, não se manifestou, conclusivamente, sobre a matéria.

Enfim, em futuro próximo esse tema pode não mais ser pontiagudo, como o é atualmente, porquanto, o entendimento quanto a questão pode ser unificado dentro do Ministério Público.

E, por mais que seja interessante o debate pelas razões aventadas de parte à parte, a consolidação do entendimento, seja para um lado, seja para o outro, é o que se aguarda e espera, em nome do princípio da impessoalidade, eficiência e segurança jurídica para com todos.

\subsection{Jurisprudência à luz do CPC/2015}

Em relação ao tema da intervenção ministerial na usucapião, praticamente inexiste jurisprudência sobre o tema ainda, uma vez que, como dito no sub-capítulo anterior, tem o Ministério Público, a princípio, atuado em toda e qualquer ação de usucapião, assim como ocorria com o antigo CPC.

Assim, por não haver uma posição consolidada da Instituição assentada pelo seu órgão de cúpula, mesmo os membros com posicionamento renovado sobre a questão seguem atuando por cautela, atendendo as razões já apontadas. 
Por outro lado, quanto as ações possessórias, a situação é mais estável, conforme os julgados abaixo em tela:

APELAÇÃO CÍVEL. DIREITO CIVIL E PROCESSUAL CIVIL. AÇÃO DE DESPEJO. INTERESSE REFLEXO DE MENOR. DESNECESSIDADE DE INTIMAÇÃO DO MEMBRO DO MINISTÉRIO PÚBLICO. CERCEAMENTO DE DEFESA. INOCORRÊNCIA. JUIZ QUE É O DESTINATÁRIO FINAL DA PROVA. RECURSO A QUE SE NEGA PROVIMENTO. 1. A desocupação do imóvel não enseja a perda superveniente do interesse recursal, uma vez que a parte simplesmente deu cumprimento à ordem judicial emanada pelo d. juízo a quo. 2. O fato de um dos residentes do imóvel, objeto desta ação de despejo, ser menor, não é motivo apto, de per si, a justificar a intervenção ministerial. Trata-se, na verdade, de interesse reflexo e indireto. Precedente do C. STJ. 3. Inexiste cerceamento de defesa no caso, eis que, nos termos do artigo 130 do Código de Processo Civil de 1973, o juiz é o destinatário da prova e pode indeferir a produção daquelas que entender protelatórias e inúteis ao deslinde do processo. Precedente. 4. Recurso a que se nega provimento. (TJ/RJ, Apelação de no 0049479-97.2013.8.19.0002, Des. Rel. Gilberto Clóvis Farias Matos, Décima Quinta Câmara Cível, julgado em 02 ago. 2016). (grifou-se).

APELAÇÃO CÍVEL. DIREITO CIVIL. AÇÃO DEMOLITÓRIA. DIREITO DE VIZINHANÇA. CONSTRUÇÃO IRREGULAR EM ÁREA COMUM. LAUDO PERICIAL CONCLUSIVO. SENTENÇA DE PROCEDÊNCIA. IRRESIGNAÇÃO DA PARTE RÉ. APELO DO RÉU PUGNANDO PELA REFORMA DA SENTENÇA SOB O FUNDAMENTO DO DECISUM DISTANCIAR-SE DA REALIDADE BRASILEIRA AO NEGAR A EXISTÊNCIA DO DIREITO DE LAJE E AO DESALOJAR FAMÍLIA HUMILDE COM MENORES. NECESSIDADE DE INTERVENÇÃO DO MINISTÉRIO PÚBLICO. Desnecessidade de intervenção do Ministério Público na demanda, pois trata-se de mera ação demolitória, sobretudo porque as partes do processo são capazes e não há interesse público. Direito de vizinhança, consubstanciada na ilegalidade da construção realizada pelo réu. Construção de um terceiro pavimento, levantamento de colunas e cintas de concreto junto à parede do imóvel dos autores. Obstrução da ventilação e iluminação das janelas da casa que dão para a área comum. Inteligência dos artigos 1.277, 1.280 e 1.299 do Código Civil. Inexistência de dúvidas quanto à irregularidade da obra, porquanto 
edificada sem projeto e licenciamento previamente aprovados pela municipalidade, bem como construída sobre a área comum. Prova pericial observou a existência de dano e fissuras no pilar originadas por sobrecarga. Imóveis construídos em área carente igualmente necessitam de licença do órgão público seja para construção ou ampliação. Ausência de comprovação quanto à construção ter iniciado antes da aquisição do imóvel por parte dos apelados. Demais argumentos impertinentes ao deslinde da causa. DESPROVIMENTO DO RECURSO (TJ/RJ, Apelação de no 0018473-66.2009.8.19.0211, Des. Rel. Lúcio Durante, Décima Nona Câmara Cível, julgado em 02 ago. 2016). (grifou-se).

APELAÇÃO CÍVEL. EMBARGOS DE TERCEIROS. AÇÃO DE COBRANÇA DE COTA CONDOMINIAL PROPOSTA EM FACE DO EX-MARIDO E PAI DOS EMBARGANTES/APELANTES. ALEGAÇÃO DA EMBARGANTE/APELANTE DE QUE ELA DEVERIA TER SIDO CITADA NA AÇÃO DE COBRANÇA DE COTA CONDOMINIAL, MOVIDA EM FACE DO SEU EXMARIDO, PELO FATO DE SER COPROPRIETÁRIA. ALEGAÇÃO DE NECESSIDADE DE INTERVENÇÃO DO MINISTÉRIO PÚBLICO, CONSIDERANDO QUE RESIDE NO IMÓVEL OBJETO DA PENHORA O MENOR, FILHO DO EXECUTADO. SENTENÇA DE IMPROCEDÊNCIA QUE SE MANTÉM. DESNECESSIDADE DE INTERVENÇÃO DO MINISTÉRIO PÚBLICO, TENDO EM VISTA QUE A EXECUÇÃO É DIRIGIDA AO PAI DA CRIANÇA. APELANTE QUE NÃO COMPROVA A QUALIDADE DE COPROPRIETÁRIA, NÃO TENDO SE DESINCUMBIDO DO ÔNUS DO ARTIGO 333, I, DO CPC. PRECEDENTES JURISPRUDENCIAIS. NEGADO PROVIMENTO AO RECURSO (TJ/RJ, Apelação de $n^{\circ}$ 001624029.2014.8.19.0209, Des. Rel. Inês Da Trindade Chaves De Melo, Sexta Câmara Cível, julgado em 13 jul. 2016). (grifou-se).

APELAÇÃO CÍVEL. REINTEGRAÇÃO DE POSSE. NULIDADE DA SENTENÇA. REJEIÇÃO. USUCAPIÃO. MATÉRIA DE DEFESA. AUSÊNCIA DE NECESSIDADE DE INTERVENÇÃO DO MINISTÉRIO PÚBLICO. IMPOSSIBILIDADE DE RECONHECIMENTO DA PRESCRIÇÃO AQUISITIVA E DO DIREITO DE PROPRIEDADE NO FEITO POSSESSÓRIO. REMESSA À VIA PRÓPRIA. MANUTENÇÃO DA IMPROCEDÊNCIA DO PEDIDO POSSESSÓRIO POR FUNDAMENTO DIVERSO. PROVIMENTO PARCIAL DO RECURSO. 1. Não se tratando de ação de usucapião, mas de ação de 
reintegração de posse, e versando sobre direito individual sem interesse público, não há que se falar em obrigatoriedade de intervenção do Ministério Público no feito, razão pela qual se rejeita a nulidade da sentença. 2. $O$ acolhimento da exceção de usucapião não confere aos réus um título executivo judicial, sendo necessário o ajuizamento de ação própria para a aquisição originária da propriedade, pois a alegação de usucapião em matéria de defesa se faz a título de defesa de mérito indireta, não com o objetivo de ver reconhecida a prescrição aquisitiva, mas como causa extintiva do direito do autor (art. 333, II do CPC de 1973).Assim, a sentença não atingirá propriamente o interesse público, mas apenas o interesse individual daquele que pretende a proteção possessória. 3. Nas ações possessórias com procedimento especial disciplinado pelo Código de Processo Civil de 1973, a discussão sobre o domínio é defesa, haja vista a causa de pedir próxima referir-se apenas à posse, sua comprovação e sua turbação ou esbulho, não se confundindo aquela com o direito real de propriedade. 4. A arguição da usucapião em defesa não tem o condão de substituir a ação própria de usucapião, que, aliás, tem inúmeros requisitos específicos de observância obrigatória. 5. A prescrição aquisitiva (usucapião) é forma originária de aquisição de propriedade pelo decurso do tempo não se confundindo com a prescrição extintiva do direito do autor de pleitear a posse do imóvel. 6. Verificados os requisitos para a comprovação da usucapião alegada como matéria de defesa, deve ser mantida a improcedência do pleito reintegratório, esclarecendo, entretanto, que o direito à propriedade para ser reconhecido deverá ser postulado em procedimento próprio. 7 . Não se tratando de prescrição extintiva, afigura-se inaplicável a extinção prevista no inciso IV art. 269 do CPC de 1973, impondo-se acolher o pleito recursal neste ponto para manter a extinção do processo com resolução de mérito, por fundamento diverso, qual seja, nos termos do art. 269, I, do CPC de 1973, suplantado pelo art. 487, I, do NCPC. 9. Provimento parcial do recurso (TJ/RJ, apelação de $\mathrm{n}^{\circ}$ 0001008-49.2009.8.19.0080, Décima Sétima Câmara Cível, Des. Rel. Elton Martinez Carvalho Leme, julgado em 28 jun. 2017)

APELAÇÃO - AÇÃO DE REINTEGRAÇÃO DE POSSE PRELIMINAR DE NULIDADE DA SENTENÇA POR AUSÊNCIA DE INTIMAÇÃO DA PROCURADORA - REJEITAR PRELIMINAR DE NULIDADE POR AUSÊNCIA DE INTIMAÇÃO DO MINISTÉRIO PÚBLICO - REJEITAR AUSÊNCIA DE INTERESSE NO FEITO - AGRAVO RETIDO PROVIMENTO NEGADO - IMPOSSIBILIDADE DE DECRETAÇÃO 
DA REVELIA - APALICAÇÃO DO ART. 320, I, CPC/73 ESBULHO NÃO COMPROVADO - AUSÊNCIA DOS REQUISITOS DO ART. 927 DO $\mathrm{CPC} / 73$. O não cadastramento de uma das procuradoras da parte autora, assim como a ausência de sua intimação para a audiência de instrução e julgamento não impõe a nulidade do feito quando todos os atos processuais foram praticados por procurador que estava cadastrado e quando a própria parte afirma que deixou de comparecer na referida audiência por equívoco. Também não há falar em nulidade por ausência de intimação do Ministério Público quando o feito não desafia a sua intervenção. Deve ser considerada a data da juntada do mandado de citação aos autos para fins de contagem do prazo para a contestação quando uma das partes não compareceu de forma espontânea nos autos, mostrando-se incabível a decretação da revelia, nos termos do art. 320, I, CPC/73. Incumbe à parte autora na ação de reintegração comprovar a anterioridade de sua posse, da turbação ou do esbulho praticado pelo réu e da data em que ocorreu um ou outro. Não tendo ela se desincumbido do ônus, a improcedência do pedido inicial é medida que se impõe. (TJ/MG, Apelação Cível $\mathrm{n}^{\circ}$ 1.0671.12.001545-6/003, Des. Rel. Alberto Henrique , 13 a Câmara Cível, julgado em 19 out. 2017, publicação da súmula em 27 out. 2017).(grifou-se).

AÇÃO DE REINTEGRAÇÃO DE POSSE - ESBULHO - PROVA PROCESSO - NULIDADE - INTERVENÇÃO DO MINISTÉRIO PÚBLICO - DESNECESSIDADE - FALTA DE INTERESSE PÚBLICO.

A proteção possessória se faz necessária, ante a prova do esbulho narrado na inicial. A nulidade do processo, pela não intervenção do Ministério Público, configura-se proposição recursal de todo falsa, porquanto desnecessária é a sua atuação na causa, diante da ausência insofismável de interesse público. (TJ/MG, Apelação Cível $\mathrm{n}^{\mathrm{o}}$ 1.0520.07.015797-6/005, Des. Rel. Saldanha da Fonseca , $12^{\mathrm{a}}$ Câmara Cível, julgado em 04 abr. 2018, publicação da súmula em 13 abr. 2018). (grifou-se).

AGRAVO DE INSTRUMENTO - AÇÃO DE REINTEGRAÇÃO DE POSSE - PRELIMINAR - NULIDADE DA DECISÃO, POR AUSÊNCIA DE MANIFESTAÇÃO DO MINISTÉRIO PÚBLICO AUSÊNCIA DE NECESSIDADE DE INTERVENÇÃO OBRIGATÓRIA NO FEITO - INEXISTÊNCIA DE UMA DAS HIPÓTESES DO ART. 178, DO CPC - REJEIÇÃO - PEDIDO LIMINAR - PRESENÇA DOS REQUISITOS CONSTANTES NO ART. 561, DO CPC - COMPROVAÇÃ̃O DA POSSE ANTERIOR DA 
AGRAVADA SOBRE O IMÓVEL E DO ESBULHO PRATICADO PELA AGRAVANTE, HÁ MENOS DE ANO E DIA INDEFERIMENTO DA MEDIDA.

- Deve ser rejeitada a preliminar de nulidade da decisão, por ausência de manifestação do Ministério Público, quando o feito não se enquadrar em nenhuma das hipóteses de intervenções obrigatórias descritas no art. 178, do CPC, e, principalmente, quando o "Parquet" esclarece não possuir interesse no processo.

-A demonstração da posse anterior exercida pela Autora sobre o imóvel objeto da ação e do esbulho praticado pela parte Ré, há menos de ano e dia, ensejam o deferimento da liminar de reintegração de posse sobre o bem, diante dos preenchimentos dos requisitos constantes no art. 561, do CPC. (TJ/MG, Agravo de Instrumento $\mathrm{n}^{\circ}$ 1.0352.17.004240-7/001, Des. Rel. Roberto Vasconcellos , $17^{\mathrm{a}}$ Câmara Cível, julgado em 01 mar. 2018, publicação da súmula em 13 mar. 2018). (grifou-se). 


\section{Conclusão}

\subsection{Implicações práticas e efeitos da modificação legislativa}

Diante de todo o exposto, verifica-se que o Ministério Público nas ações possessórias salvaguardará a sua atribuição, na medida em que as circunstâncias legitimadoras elencadas pelo antigo Código de Processo Civil foram praticamente repetidas pelo Novo CPC.

Assim, tal funcionamento, como custos legis, se dará quando presentes as cláusulas gerais de intervenção, isto é, o interesse público ou social, o conflito pela posse coletiva de terra urbana ou rural, bem como nas causas em que houver interesse de incapaz, este devendo ser entendido, como demonstrado, como interesse subjacente a causa, na qualidade de parte do processo, não acobertado, portanto, o interesse meramente reflexo.

Agora, quanto as ações de usucapião, a mudança trazida pelo legislador é evidente, porquanto alterou a previsão legal sobre o tema, suprimindo do direito positivado o capítulo concernente as ações de usucapião que previa, obrigatoriamente, por previsão expressa e inequívoca, a atuação do Ministério Público em demandas dessa natureza.

Outrossim, indiscutível, em primeiro plano, a desnecessidade de intervenção nas ações de usucapião de bens móveis (art. $1^{\circ}, \mathrm{V}$ da Deliberação $n^{\circ}$ 20-A/2008, Órgão Especial do Colégio de Procuradores de Justiça, MP/RJ), por posicionamento pacífico dentro da Instituição desde a vigência do CPC/1973.

Por outro lado, quanto aos bens imóveis, em que pese um certo grau de resistência, é inegável a modificação do funcionamento do Parquet nas ações de usucapião, pelas razões já aduzidas.

Com efeito, no cenário processual atual deverá o MP intervir como fiscal da lei: (i) nas ações de usucapião em que presentes as cláusulas gerais de 
intervenção, quais sejam, interesse social, interesse público, interesse de incapaz e litígio coletivo sobre a posse de terra urbana ou rural, nos termos do art. 178, CPC/2015, (ii) nas ações de usucapião especial urbana, pelo intrínseco cunho social, bem como expressa previsão legal do art. $12, \S 1^{\circ}$, da lei 12.257/2001, (iii) nas ações de usucapião especial rural, em decorrência do forte caráter social da modalidade, à luz do art. 178, I, CPC/2015, (iv) na usucapião especial coletiva, por versar sobre litígio coletivo sobre a posse e possuir, também, íntimo interesse social, na forma do art. 178, I e III, CPC/2015, (v) nas ações de usucapião sem registro, por haver interesse público na regularização do imóvel, conforme interpretação do estabelecido no art. 167, I, 28 e art. 176, caput, $\S 1^{\circ}$, I, c/c art. 200 e 202, da lei de Registro Públicos (lei 6.015/1973).

Além disso, inexistindo cláusula geral de intervenção ministerial, não funcionará mais o Ministério Público nas ações de usucapião ordinária e extraordinária e por abandono do lar, sendo as duas primeiras espécies mais comuns na prática forense, em razão da menor quantidade de requisitos para a declaração da prescrição aquisitiva.

Então, em que pese, em linhas gerais, a retirada de causa legitimadora basicamente em três das modalidades de usucapião, a modificação é impactante, vez que reduzirá, e muito, o funcionamento do Parquet, por essas serem as ações que mais demandam a atribuição da Instituição.

Tendo em vista que as ações mais corriqueiras no Ministério Público são: ações indenizatórias de plano de saúde, indenizatórias de seguro de vida, de acidente de trabalho, de usucapião e de mandado de segurança em sede de juizados especiais ${ }^{71}$, nota-se que as ações de usucapião estão entre as 5 mais triviais que chamam a intervenção do Ministério Público.

${ }^{71}$ GOUVÊA, Marcos Antonio Maselli de Pinheiro et al. Op. cit. p. 14-36. 
Destarte, uma alteração da atribuição em qualquer dessas ações traz um forte impacto em termos de demanda de trabalho do MP, pois são ações "de massa" por assim dizer.

Isto posto, a mudança acima aventada permitirá uma maior atenção e melhora da qualidade nas promoções do Ministério Público, que terá uma atuação mais restrita, visto que terá uma demanda de intimações processuais significativamente reduzida.

Isso propiciará uma maior eficiência, no que diz respeito a uma prestação de resposta mais célere e mais cuidadosa por parte do Parquet, em decorrência da menor quantidade de processos que invoquem a sua intervenção.

E, ressalta-se, essa diminuição de atribuição não é uma justificativa a melhora do trabalho, mas uma consequência lógica e racional, até porque essa diminuição se dá legitimamente, porque, como visto, desnecessária se fará a mantença do funcionamento do MP em certas hipóteses.

Noutro giro, para as partes envolvidas nas ações que não convoquem mais o atuar do Parquet isso também é benéfico, uma vez que o processo demora substancialmente mais quando o Ministério Público está envolvido e participando.

Isso se dá não só pelo tempo demandado para as manifestações dos órgãos do MP, mas também pela demora do cartório do juízo em impulsionar os processos adequadamente, seja pelo assoberbamento de trabalho, ou mesmo por própria desídia de seus funcionários.

Dessa forma, sendo desnecessária a atuação do Ministério Público, não há sentido justificável em atrasar a prestação jurisdicional por um conservadorismo de chamá-lo ao processo, em observância ao art. $5^{\circ}$, LXXVIII, CRFB/1988 c/c art. 6, $\mathrm{CPC} / 2015$, que positiva o princípio da duração razoável do processo no ordenamento jurídico brasileiro. 
Por outro lado, deve-se zelar pela intervenção técnica e, de fato, legítima, como fiscal da lei, do Parquet, em acatamento a realização de seu múnus legal e constitucionalmente estabelecido pelo legislador pátrio, sendo, à visto disso, prescindível qualquer funcionamento processual à margem dessa nova conjectura imposta, seja em benefício interno da Instituição, seja em prol do interesse comum dos litigantes no processo. 


\section{BIBLIOGRAFIA}

PEREIRA, Caio Mário da Silva. Instituições de Direito Civil. Volume IV. Direitos Reais. $23^{\mathrm{a}}$ ed. Rio de Janeiro, Forense, 2015. 397 p.

LEITE, Gisele. Propriedade em geral em poucas palavras. In: Âmbito Jurídico, Rio Grande, XI, n.50, fev. 2008. Disponível em <http://www.ambitojuridico.com.br/site/?n_link=revista_artigos_leitura\&artigo_id=4556\&revista_ caderno=7>. Acesso em 10 nov. 2017.

CARVAlHO, Fabio Rodrigues de. Diferença entre o Ius Possessionis e o Ius Possidendi. Disponível em <https://lfg.jusbrasil.com.br/noticias/47734/qual-adiferenca-entre-jus-possessionis-e-por-jus-possidendi>. Acesso em 12 nov. 2017.

GONÇALVES, Carlos Roberto. Direito civil brasileiro: direito das coisas. $6^{\mathrm{a}}$. ed. São Paulo: Saraiva, 2011. 672 p.

BLOG, Direito Direto. Disponível em <https://direitodiretoblog.wordpress.com/2016/11/26/o-mero-detentor-dacoisa-pode-se-valer-da-autotutela-desforco-imediato>. Acesso em 19 nov. 2017.

DIAS, Nadir Silveira. Benfeitorias em imóveis: Considerações gerais. In: Âmbito Jurídico, Rio Grande, II, n. 5, maio 2001. Disponível em: $<$ http://www.ambito-

juridico.com.br/site/?n_link=revista_artigos_leitura\&artigo_id=2027\&revista_ caderno=7>. Acesso em 20 nov. 2017.

BRASIL. Código Civil. Organização Yussef Said Cahali. 15ª ed. rev. ampl. e atual. São Paulo. RT, 2013.

BUENO, Julio César et al.. Ações possessórias e reivindicatórias - distinção e aspectos controversos. Disponível em <http://www.migalhas.com.br/dePeso/16,MI24726,61044Acoes+possessorias+e+reivindicatorias+distincao+e+aspectos>. Acesso em 08 dez. 2017.

ZULIANI, Matheus Stamillo Santarelli. Posse justa e posse injusta: aplicações práticas e teóricas. Disponível em <http://www.migalhas.com.br/dePeso/16,MI64980,101048- 
Posse+justa+e+posse+injusta+aplicacoes+praticas+e+teoricas>. Acesso em 09 dez. 2017.

MELLO, Bernardo de. Quais as consequências práticas da distinção entre posse de boa-fé e posse de má-fé?. Disponível em $<$ https://direitodiario.com.br/consequencias-praticas-distincao-posse-boa-fe-ede-ma-fe/>. Acesso em 15 dez. 2017.

TARTUCCE, Flávio. Direito Civil. Direito das Coisas, $9^{a}$ ed. rev., atual e ampliada. Rio de Janeiro: Forense, 2017. 396 p.

A Usucapião especial urbana por abandono do lar conjugal. Disponível em <https://flaviotartuce.jusbrasil.com.br/artigos/121820005/ausucapiao-especial-urbana-por-abandono-do-lar-conjugal>. Acesso em 16 mar. 2018.

PAIVA, Daniela Reetz de. Interversão do Caráter da Posse. Disponível em: <http://www.emerj.tjrj.jus.br/serieaperfeicoamentodemagistrados/paginas/serie s/16/direitosreais_42.pdf >. Acesso em 15 jan. 2018.

MARTINO, Jean de. Da possibilidade da posse precária ser usucapida. Disponível em <https://jeandemartino.jusbrasil.com.br/artigos/111812290/dapossibilidade-da-posse-precaria-ser-usucapida>. Acesso em 18 jan. 2018.

COSTA, Samara Danitielle. A função social da posse. Disponível em <http://www.ambitojuridico.com.br/site/?n_link=revista_artigos_leitura\&artig o_id=12222>. Acesso em 20 fev. 2018.

OLIVEIRA, Camila Alves et al. Teoria e aplicabilidade da função social da posse e da propriedade nos direitos reais enquanto instrumento de efetivação dos direitos fundamentais. <http://www.ambitojuridico.com.br/site/index.php?n_link=revista_artigos_leitura\&artigo_id=8411 >. Acesso em 20 fev. 2018.

GURJÃO, Víctor. Posse: conceito, teorias fundamentais e classificação. Disponível em <https://victorgurjao.jusbrasil.com.br/artigos/207694906/posseconceito-teorias-fundamentais-e-classificacao>. Acesso em 22 fev. 2018.

ARAUJO, Wilclem de Lázari. A função social e os bens móveis. Disponível em <https://www.direitonet.com.br/artigos/exibir/7825/A-funcao-social-e-osbens-moveis>. Acesso em 25 fev. 2018. 
GOMES, Orlando. Direitos reais.18. ed. Atual. e notas de Humberto Theodoro Junior. Rio de Janeiro: Forense, 2002. 436 p.

FARIAS, Cristiano Chaves; ROSENVALD, Nelson. Curso de Direito Civil: Direitos Reais. v. 5. $8^{\text {a }}$ ed. Revista, ampliada e atualizada. Salvador: JusPodvim, 2012.

FERREIRA, Damares. O aspecto funcional da propriedade urbana na Constituição Federal de 1988. Disponível em <http://www.ambitojuridico.com.br/site/index.php?n_link=revista_artigos_leitura\&artigo_id=4053 >. Acesso em 02 mar. 2018.

MOESCH, Frederico Fernandes. O princípio da função social da propriedade e sua eficácia. Revista Jus Navigandi, ISSN 1518-4862, Teresina, ano 10, n. 880, 30 nov. 2005. Disponível em: <https://jus.com.br/artigos/7645>. Acesso em: 04 mar. 2018.

ITO, Michel; ITO, Lilian Cavalieri. Da propriedade: conceituação, poderes e características. Boletim Jurídico, Uberaba/MG, a. 13, no 1509. Disponível em: <https://www.boletimjuridico.com.br/doutrina/artigo/4480/da-propriedadeconceituacao-poderes-caracteristicas> Acesso em: 09 mar. 2018.

PEREA, Nayara Moreno. <https://jus.com.br/artigos/42784/a-perda-dapropriedade-urbana-pelo-abandono-aliado-ao-nao-pagamento-dos-tributos-e-opapel-dos-municipiosA perda da propriedade urbana pelo abandono aliado ao não pagamento dos tributos e o papel dos Municípios>. Acesso em 10 mar. 2018.

SANTOS, Frederico Fernandes dos. Desapropriação por iniciativa privada. In: Âmbito Jurídico, Rio Grande, XIX, n. 147, abr 2016. Disponível em: $<$ http://www.ambitojuridico.com.br/site/index.php?n_link=revista_artigos_leitura\&artigo_id=1660 9\&revista_caderno=7>. Acesso em 11 mar. 2018.

NETTO, Roberta de Freitas. Propriedade E Domínio: Uma Releitura À Luz Do Princípio Da Função Social. Disponível em <https://bdjur.stj.jus.br/jspui/bitstream/2011/18445/Propriedade_e_Dom\%C3\% ADnio.pdf>. Acesso em 16 mar. 2018.

SALLES, José Carlos de Moraes. Usucapião de Bens Imóveis e Móveis. $6^{\mathrm{a}}$ ed. rev., ampl. e atual. de acordo com o Código Civil de 2002. São Paulo: Editora Revistas dos Tribunais, 2005. 573 p. 
OLIMPIO, Daniel Lobo. Usucapião Coletivo. Disponível em <http://www.egov.ufsc.br/portal/sites/default/files/anexos/9215-9214-1PB.pdf>. Acesso em 27 abr. 2018.

GOUVÊA, Marcos Antonio Maselli de Pinheiro et al. Manual de atuação funcional das Promotorias de Justiça Cíveis. 149 p.

SIGNORINI, Terezinha de Jesus Souza et. al. Consulta $n^{\circ}$ 66/2014 - CAOP Cível.

<http://www.civel.mppr.mp.br/arquivos/File/consulta_66_sao_joao_triunfo_us ucapiao_imovel_rural_sem_registro_atribuicao_mp_repercussoes_registro_pu blico.pdf>. Acesso em 11 mai. 2018.

TJ/RJ, Apelação no0030849-38.2010.8.19.0021, Décima Terceira Câmara Cível, Des. Rel. Sirley Abreu Biondi, julgado em 01 dez. 2014.

TJ/RJ, Apelação n o 0073929-81.2012.8.19.0021, Terceira Câmara Cível, Des. Rel. Helda Lima Meireles, julgado em 21 out. 2014.

TJ/RJ, Apelação no 0021376-45.1997.8.19.0001, Quarta Câmara Cível, Des. Rel. Marco Antonio Ibrahim, julgado em 07 out. 2014.

TJ/RJ, Apelação n ${ }^{\circ}$ 0012242-37.2006.8.19.0014, Décima Segunda Câmara Cível, Des. Rel. CherubinHelcias Schwartz Júnior, julgado em 07 out. 2014.

TJ/RJ, Apelação no 0001703-50.2005.8.19.0045, Vigésima Segunda Câmara Cível, Des. Rel. Carlos Eduardo Moreira Da Silva, julgado em 02 out. 2014.

TJ/RS, Apelação Cível no 70056520778, Vigésima Câmara Cível, Des. Rel. Walda Maria Melo Pierro, julgado em 12. mar. 2014.

TJ/RS, Apelação Cível no 70056775117, Décima Nona Câmara Cível, Des. Rel. Mylene Maria Michel, julgado em 29 abr. 2014.

TJ/SC, Apelação Cível no 2014.063571-0, Terceira Câmara de Direito Civil, Des. Rel. Regina Aparecida Soares Ferreira, julgado em 18 nov. 2014.

TJ/SC, Apelação Cível no 2012.077089-8, de Braço do Norte, Sexta Câmara de Direito Civil, Des. Rel. Ronei Danielli, julgado em 07 mar. 2013.

TJ/PA, Apelação Cível de nº 2009.02737929-91, Des. Rel. Marneide Trindade Pereira Merabet, julgado em 25 mai. 2009. 
TJ/RJ, Apelação cível $n^{\circ}$ 0126698-68.2008.8.19.0001, Décima Segunda Câmara Cível, Rel. Des. Cherubin Helcias Schwartz Júnior, julgado em: 13 mar. 2014.

TJ/SC, Apelação Cível no 1998.003813-8, de Blumenau, Des. Rel. Jorge Schaefer Martins, Segunda Câmara de Direito Civil, julgado em 10 nov. 2005.

TJ/RS, Agravo de Instrumento no 70061223566, Vigésima Câmara Cível, Des. Rel. Glênio José Wasserstein Hekman, Julgado em 27 out. 2014.

TJ/RS, Apelação Cível no 70048092266, Décima Sétima Câmara Cível, Des. Rel. Luiz Renato Alves da Silva, julgado em 17 abr. 2014.

TJ/RJ, Agravo de Instrumento $n^{\circ}$ 0046720-40.2011.8.19.0000, Quarta Câmara Cível, Rel. Des(a). Marcelo Lima Buhatem, julgado em 13 abr. 2012.

TJ/RJ, Apelação Cível no 0019990-87.2012.8.19.0054, Vigésima Câmara Cível, Rel. Des(a). Leticia De Faria Sardas, julgado em 12 nov. 2014.

TJ/RJ, Apelação de no 0049479-97.2013.8.19.0002, Des. Rel. Gilberto Clóvis Farias Matos, Décima Quinta Câmara Cível, julgado em 02 ago. 2016.

TJ/RJ, Apelação de no 0018473-66.2009.8.19.0211, Des. Rel. Lúcio Durante, Décima Nona Câmara Cível, julgado em 02 ago. 2016.

TJ/RJ, Apelação de no 0016240-29.2014.8.19.0209, Des. Rel. Inês Da Trindade Chaves De Melo, Sexta Câmara Cível, julgado em 13 jul. 2016.

TJ/RJ, apelação de ${ }^{\circ}$ 0001008-49.2009.8.19.0080, Décima Sétima Câmara Cível, Des. Rel. Elton Martinez Carvalho Leme, julgado em 28 jun. 2017.

TJ/MG, Apelação Cível no 1.0671.12.001545-6/003, Des. Rel. Alberto Henrique , 13ª Câmara Cível, julgado em 19 out. 2017, publicação da súmula em 27 out. 2017.

TJ/MG, Apelação Cível no 1.0520.07.015797-6/005, Des. Rel. Saldanha da Fonseca , 12 $2^{\mathrm{a}}$ Câmara Cível, julgado em 04 abr. 2018, publicação da súmula em 13 abr. 2018.

TJ/MG, Agravo de Instrumento $\mathrm{n}^{\circ}$ 1.0352.17.004240-7/001, Des. Rel. Roberto Vasconcellos , 17ª Câmara Cível, julgado em 01 mar. 2018, publicação da súmula em 13 mar. 2018. 